\title{
Advanced Oxidation Processes and Biotechnological Alternatives for the Treatment of Tannery Wastewater
}

\author{
Néstor Andrés Urbina-Suarez ${ }^{1,2}$, Fiderman Machuca-Martínez ${ }^{1,3, *(\mathbb{D})}$ and Andrés F. Barajas-Solano ${ }^{2}$ (i) \\ 1 School of Natural Resources and Environment, Universidad del Valle, Cali 760015, Colombia; \\ nestorandresus@ufps.edu.co \\ 2 Department of Environmental Sciences, Universidad Francisco de Paula Santander, \\ Av. Gran Colombia No. 12E-96, Cucuta 540003, Colombia; andresfernandobs@ufps.edu.co \\ 3 Centro de Excelencia en Nuevos Materiales-CENM, Escuela de Ingeniería Química, Universidad del Valle, \\ Cali 760015, Colombia \\ * Correspondence: fiderman.machuca@correounivalle.edu.co
}

Citation: Urbina-Suarez, N.A.;

Machuca-Martínez, F.; Barajas-Solano, A.F. Advanced Oxidation Processes and Biotechnological Alternatives for the Treatment of Tannery Wastewater Molecules 2021, 26, 3222. https:// doi.org/10.3390/molecules26113222

Academic Editor: Marcello Brigante

Received: 17 April 2021

Accepted: 21 May 2021

Published: 27 May 2021

Publisher's Note: MDPI stays neutral with regard to jurisdictional claims in published maps and institutional affiliations.

Copyright: (c) 2021 by the authors. Licensee MDPI, Basel, Switzerland. This article is an open access article distributed under the terms and conditions of the Creative Commons Attribution (CC BY) license (https:// creativecommons.org/licenses/by/ $4.0 /)$.

\begin{abstract}
The tannery industry is one of the economic sectors that contributes to the development of different countries. Globally, Europe and Asia are the main producers of this industry, although Latin America and Africa have been growing considerably in recent years. With this growth, the negative environmental impacts towards different ecosystem resources as a result of the discharges of recalcitrated pollutants, have led to different investigations to generate alternative solutions. Worldwide, different technologies have been studied to address this problem, biological and physicochemical processes have been widely studied, presenting drawbacks with some recalcitrant compounds. This review provides a context on the different existing technologies for the treatment of tannery wastewater, analyzing the physicochemical composition of this liquid waste, the impact it generates on human health and ecosystems and the advances in the different existing technologies, focusing on advanced oxidation processes and the use of microalgae. The coupling of advanced oxidation processes with biological processes, mainly microalgae, is seen as a viable biotechnological strategy, not only for the removal of pollutants, but also to obtain value-added products with potential use in the biorefining of the biomass.
\end{abstract}

Keywords: wastewater; AOPs; tannery; microalgae; biological process; leather industry

\section{Introduction}

Currently, there are various industrial processes that contribute to the deterioration of water quality; most require the use of highly polluting substances for terrestrial and aquatic ecosystems; therefore, it is imperative to apply a treatment before its discharge in different water bodies. The tanning sector allows the transformation of degradable animal leather into non-degradable leather by eliminating impurities and unnecessary materials [1]; however, this process generates different residues that represent a significant environmental problem, requiring specific treatments, which are expensive and inaccessible in many developing countries. [2]. In the global context, Asia together with Latin America and Europe are the main leather producers in the world [3,4] (Figure 1). It is estimated that the budget of this business in Europe is approximately 8 billion euros per year, due to the more than 3000 companies that employ 50,000 people, demonstrating their competitiveness in the global market [5]. In recent years, Latin America and Africa have increased the annual growth rate given the consumption of leather in these places [3]. Italy is the main leather producer on the European continent, owns $60 \%$ of the companies and exports more than $70 \%$ of the total production in Europe; it owns $15 \%$ of the world leather production, and in the European Union, it is the main producer with $65 \%$ of the total manufacture. [6]. In Latin America, Brazil and Argentina stand out in this sector; they have a significant number of emerging companies with great competitiveness in the market, exporting their 
products to countries such as China, Hong Kong, Vietnam and the United States. Globally, Colombia represents $5 \%$ of the tanning industry production, and in the Latin American context, it ranks 6th as a producer in this industry [5].

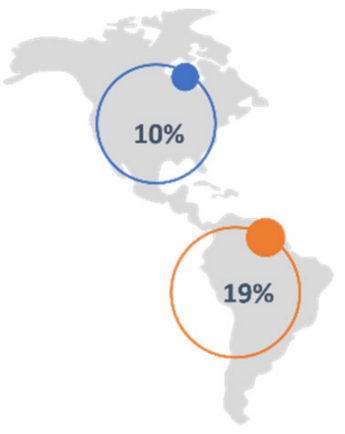

NORTH AMERICA

1230 thousand tons per year. Annual growth rate of $0.3 \%$

\section{LATIN AMERICA}

2359 thousand tons per year. $1.3 \%$ annual growth rate
- AFRICA

1616 thousand tons per year. $1.8 \%$ annual growth rate.

\section{EUROPE}

2359.12 thousand tons per year. $0.5 \%$ annual growth rate.

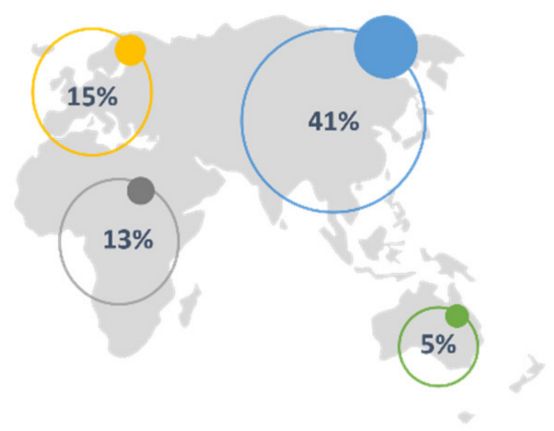

ASIA

5067 thousand tons per year. 2.1 $\%$ annual growth rate.

\section{OCEANIA}

585 thousand tons per year. -0.5 $\%$ annual growth rate.

Figure 1. Global context of the leather industry.

Leather production consumes on average $10-25 \mathrm{~m}^{3}$ of water in its different stages and can generate on average 8 to $20 \mathrm{~m}^{3}$ of wastewater; this flow may vary depending on the technological development of each industry. According to Nagi et al. [2], this resource is used to transport chemical products from diffusion and in the phase of washing and extraction of undesirable compounds from the leather [7]. In this process, large amounts of wastewater are generated, significantly altering the quality of the water since they not only contain biodegradable compounds such as fats, proteins and carbohydrates, but also polluting compounds such as solvents, additives and toxic heavy metals typical of the process [8]. At least $90 \%$ of industries are reported to use basic chromium sulfate as a tanning agent $[9,10]$, chromium $(\mathrm{Cr})$ being one of the most toxic metals used in tanning and, without prior treatment, is released in effluents in toxic concentrations. The regulations of the World Health Organization (2020) recommend a reference value of $0.05 \mathrm{mg} / \mathrm{L}$ of total chromium in drinking water; above this concentration, it can exert a genotoxic and carcinogenic effect. High concentrations of chromium (VI) cause the deterioration of ecosystems and have an impact on human health as they cause kidney damage, liver damage, chronic bronchitis, nasal irritation, cancer, and DNA damage among other things [11,12]; these effects have led governments to apply stricter regulations and promote effective treatments to reduce the risk of contamination. Over the years, various techniques for treating tannery wastewater have been studied, focused on the removal of pollutants, particularly chromium. Some of these technologies are chemical coagulation, photodegradation, biodegradation, adsorption, ozonation, electrocoagulation and reverse osmosis [13]; however, the difficulty of implementing them is related to high energy consumption, use of large areas of land, high operation and maintenance costs [14]; in the same way, in some processes, other polluting byproducts are generated [15]. The foregoing has launched various biotechnological processes, including the use of microalgae, bacteria and fungi, as sustainable and economically affordable alternatives [16].

In recent years, microalgae and cyanobacteria have been proposed as a sustainable solution for the removal of nutrients and hazardous materials from wastewater [17-20]. In relation to the treatment of wastewater from tanneries, studies with various strains are still limited, the most common being Scenedesmus sp. and Chlorella sp., obtaining 
positive and promising results [2]. Microalgae have exhibited high tolerance to adapt in this environment, as well as an important role in reducing contaminants. The biomass of the microalgae has shown an absorbent capacity during the chromium elimination process, obtaining important results with Chlorella vulgaris, where a reduction of $\mathrm{Cr}$ (VI) to $\mathrm{Cr}$ (III) was also observed, going from a highly toxic compound to one less toxic, also attributing it to biological (enzymatic pathway) and non-biological mechanisms (glutathione releasing) [21]. Likewise, the use of residual biomass from the process is a way to maximize production of energy (biofuels) and generate byproducts of commercial interest (pigments, lipids, etc.), reducing the costs of the process [22-29]. Various studies have been carried out to identify the advantages of using microalgae in tannery waters. In India, one of the three largest leather producers after China and Italy, high concentrations of $\mathrm{Pb}, \mathrm{Cr}, \mathrm{Zn}$ and $\mathrm{Cu}$ were found, and an efficiency of $60-98 \%$ of removal of these metals under different conditions was demonstrated, specifically with microalgae [30]. In Brazil, progress has been made regarding the growth of microalgae consortia under different concentrations of tannery wastewater [16].

In Colombia, several research studies have been carried out to mitigate the impacts; among them are the identification and evaluation of pollutants [31]; the use of the Eichhornia crassipes plant has been reported in pilot-scale treatment of tannery water due to its capacity to accumulate heavy metals and organic matter [32]; the genotoxic effect of tannery effluents on Salmonella typhimurium strains has also been studied, identifying a mutagenic increase and the capacity to generate DNA damage in human lymphocytes [31-33]. However, the application of microalgae in tannery wastewater has not yet been developed in depth in this country.

This review exposes the current situation of tannery wastewater treatments, focusing on the implementation of new biotechnological tools and, in more detail, on the use of microalgae as a treatment to reduce pollutant loads and the use of metabolites of microalgae in this process as a source of biofuels or byproducts of industrial interest.

\section{Pollutant Loads from Tannery Wastewaters}

Tannery wastewater is the product of a transformation process from organic matter to non-degradable matter, which requires the addition of compounds and additives that allow such transformation, generating in turn waste highly polluting not only for human health, but also for the environment [34]. These wastewaters have as main characteristics a dark brown color, a characteristic odor due to the presence of volatile organic compounds, organic and inorganic carbon, phosphorus $(\mathrm{P})$, nitrogen compounds (N) [9,35-42], fats and other highly polluting compounds at certain concentrations, such as chemical oxygen demand (COD), biological oxygen demand (BOD), total dissolved solids (TDS), chlorides, sulfates and heavy metals such as Zinc (Zn) and chromium (Cr), among other things [37,43-46]. Goswami and Mazumder [47] reported a typical characterization of tannery wastewater, where COD concentrations were observed between 500 and $11,500 \mathrm{mg}^{*} \mathrm{~L}^{-1}$, total Kjeldahl nitrogen (TKN) - 200-550 $\mathrm{mg}^{*} \mathrm{~L}^{-1}$, observing that the highest fraction is available as ammonia nitrogen $\left(\mathrm{NH}_{3}-\mathrm{N}\right)$, total chromium concentrations $(\mathrm{Cr}(\mathrm{VI})$ and $\mathrm{Cr}(\mathrm{III}))$ in a range of $5-140 \mathrm{mg}^{*} \mathrm{~L}^{-1}$, slow biodegradability due to the content of biodegradable compounds is less than $50 \%$ and very high total dissolved solids (TDS) compared to total suspended solids (TSS). Different studies have reported high values of BOD, COD and even the presence of $\mathrm{Cr}$ in effluents [13,36,39,48-55]. Other compounds have been reported in these wastewaters, finding results of acidic $\mathrm{pH}$ between $3.4 \pm 0.0351$ and $5.96 \pm 0.0351$ [56-58] and basic $\mathrm{pH}$ between $8.0 \pm 0.4$ and $11.64 \pm 0.53[37,41,46,51,52,54,55,59-61]$; in relation to TDS, typical values can have concentrations ranging from $2355 \pm 85 \mathrm{mg}^{*} \mathrm{~L}^{-1}$ to $10,000 \pm 800 \mathrm{mg}^{*} \mathrm{~L}^{-1}[9,37,39,42,61,62]$; high concentrations have been recorded that can be between 10,560 $\pm 78 \mathrm{mg}^{*} \mathrm{~L}^{-1}$ and $72,400 \pm 0.10 \mathrm{mg}^{*} \mathrm{~L}^{-1}[35,40,53-55,63]$; as for BOD, the average values can be in low ranges from $160 \pm 15.8 \mathrm{mg}^{*} \mathrm{~L}^{-1}$ to $1250 \pm 38 \mathrm{mg}^{*} \mathrm{~L}^{-1}[37,39,61,63]$ and in high ranges that fluctuate between $1500 \pm 41 \mathrm{mg}^{*} \mathrm{~L}^{-1}$ and $6000 \pm 30 \mathrm{mg}^{*} \mathrm{~L}^{-1}$ [9,49-51,53-55]. In relation 
to the total chromium concentration, values ranging from $0.83 \pm 0.028 \mathrm{mg}^{*} \mathrm{~L}^{-1}$ to $134 \pm 5.8 \mathrm{mg}^{*} \mathrm{~L}^{-1}$ have been reported $[9,35,38,40,61,64]$, as well as high ranges from $147.4 \pm 1.5$ to $3800 \pm 115 \mathrm{mg}^{*} \mathrm{~L}^{-1}[35,37,44,53,56,57,60]$, chloride-between $1101.9 \pm 1.6825 \mathrm{mg}^{*} \mathrm{~L}^{-1}[65,66]$ and $1696.6 \pm 1.8965 \mathrm{mg}^{*} \mathrm{~L}^{-1}$ and sodium-with a maximum range of $690.1 \pm 1.0504 \mathrm{mg}^{*} \mathrm{~L}^{-1}$ [67-69]. Likewise, differences in the results of raw and pretreated tannery wastewater by conventional coagulation process have been reported, where total solids (TS) results of 10,265 $\pm 1460 \mathrm{mg}^{*} \mathrm{~L}^{-1}$ and $6810 \pm 110 \mathrm{mg}^{*} \mathrm{~L}^{-1}$ were obtained. COD was $4800 \pm 350 \mathrm{mg}^{*} \mathrm{~L}^{-1}$ and $1910 \pm 174 \mathrm{mg}^{*} \mathrm{~L}^{-1}$, TKN-225 $\pm 18 \mathrm{mg}^{*} \mathrm{~L}^{-1}$ and $203 \pm 23 \mathrm{mg}^{*} \mathrm{~L}^{-1}, \mathrm{NH}_{3}-\mathrm{N}-128 \pm 20 \mathrm{mg}^{*} \mathrm{~L}^{-1}$ and $120 \pm 15 \mathrm{mg}^{*} \mathrm{~L}^{-1}$, and total chromium$95 \pm 55 \mathrm{mg}^{*} \mathrm{~L}^{-1}$ and $0.55 \pm 0.11 \mathrm{mg}^{*} \mathrm{~L}^{-1}$, respectively, showing that the coagulation process as pretreatment decreases the concentration of some parameters [70-73]. Table 1 shows different values of physicochemical characterization of tannery wastewater.

Table 1. Physicochemical characterization of different tannery wastewater.

\begin{tabular}{|c|c|c|c|c|c|c|c|}
\hline $\mathrm{pH}$ & $\begin{array}{c}\mathrm{COD} \\
\left(\mathrm{mg}^{*} \mathrm{~L}^{-1}\right)\end{array}$ & $\begin{array}{c}\text { BOD } \\
\left(\mathrm{mg}^{*} \mathrm{~L}^{-1}\right)\end{array}$ & $\begin{array}{c}\text { TDS } \\
\left(\mathrm{mg}^{*} \mathrm{~L}^{-1}\right)\end{array}$ & $\begin{array}{c}\mathrm{Cr} \\
\left(\mathrm{mg}^{*} \mathrm{~L}^{-1}\right)\end{array}$ & $\begin{array}{c}\mathrm{NH}_{3}-\mathrm{N} \\
\left(\mathrm{mg}^{*} \mathrm{~L}^{-1}\right)\end{array}$ & $\begin{array}{c}\mathrm{PO}_{4} \\
\left(\mathrm{mg}^{*} \mathrm{~L}^{-1}\right)\end{array}$ & Reference \\
\hline $\mathrm{n} / \mathrm{a}$ & $17,683 \pm 1500$ & $6000 \pm 300$ & $10,000 \pm 800$ & $\mathrm{n} / \mathrm{a}$ & 4500 & 4100 & [9] \\
\hline 7.5 & 4000 & 1400 & $\mathrm{n} / \mathrm{a}$ & $\mathrm{n} / \mathrm{a}$ & 343 & 6.6 & [13] \\
\hline $3.4-3.7$ & $5250-9600$ & $\mathrm{n} / \mathrm{a}$ & $38,200-39,400$ & $2705-3800$ & $115-136$ & $\mathrm{n} / \mathrm{a}$ & [35] \\
\hline $3.5-4$ & 6800 & $\mathrm{n} / \mathrm{a}$ & $\mathrm{n} / \mathrm{a}$ & $\mathrm{n} / \mathrm{a}$ & $\mathrm{n} / \mathrm{a}$ & 1.76 & [36] \\
\hline $8.49 \pm 0.2$ & $322 \pm 28.6$ & $160 \pm 15.8$ & $3491.3 \pm 239.4$ & $1445 \pm 67.9$ & $\mathrm{n} / \mathrm{a}$ & $5.7 \pm 0.2$ & [37] \\
\hline 7.9 & 4155 & - & $\mathrm{n} / \mathrm{a}$ & $\mathrm{n} / \mathrm{a}$ & 485 & 524 & [38] \\
\hline $8.9 \pm 0.1$ & $4500 \pm 329$ & $400 \pm 36$ & $5900 \pm 391$ & $\mathrm{n} / \mathrm{a}$ & $129.69 \pm 7.75$ & $194.61 \pm 9.8$ & [39] \\
\hline $5.84 \pm 0.02$ & $198.60 \pm 0.23$ & $6.5 \pm 0.10$ & $72,400 \pm 0.10$ & $0.83 \pm 0.28$ & $\mathrm{n} / \mathrm{a}$ & $294.4 \pm 0.22$ & [40] \\
\hline $8.45 \pm 0.18$ & $1300.00 \pm 10.0$ & $680.00 \pm 20.0$ & $3850.00 \pm 10.0$ & $7.39 \pm 0.03$ & $12.3 \pm 0.3$ & $12.5 \pm 0.5$ & [41] \\
\hline $7.45 \pm 0.00$ & $4000.00 \pm 51.20$ & $\mathrm{n} / \mathrm{a}$ & $4333.33 \pm 288.70$ & 3.22 & $2734.16 \pm 1.12$ & $6.01 \pm 0.05$ & [42] \\
\hline 4.13 & 5485 & 90 & $\mathrm{n} / \mathrm{a}$ & 2007.08 & $\mathrm{n} / \mathrm{a}$ & $\mathrm{n} / \mathrm{a}$ & [44] \\
\hline $4-9$ & 1235 & 450 & $\mathrm{n} / \mathrm{a}$ & 128.8 & $\mathrm{n} / \mathrm{a}$ & $\mathrm{n} / \mathrm{a}$ & [45] \\
\hline $11.64 \pm 0.53$ & $7200 \pm 1090$ & $1250 \pm 380$ & $\mathrm{n} / \mathrm{a}$ & $7.02 \pm 0.76$ & $\mathrm{n} / \mathrm{a}$ & $\mathrm{n} / \mathrm{a}$ & [46] \\
\hline 6.25 & 11,800 & 1200 & $\mathrm{n} / \mathrm{a}$ & 32.2 & $\mathrm{n} / \mathrm{a}$ & $\mathrm{n} / \mathrm{a}$ & [48] \\
\hline 8.36 & 5308.4 & 1952.5 & 1578 & 123.1897 & $\mathrm{n} / \mathrm{a}$ & $\mathrm{n} / \mathrm{a}$ & [49] \\
\hline 7.5 & $4291 \mathrm{mg} / \mathrm{L}$ & 2102.60 & $\mathrm{n} / \mathrm{a}$ & $\mathrm{n} / \mathrm{a}$ & $\mathrm{n} / \mathrm{a}$ & $\mathrm{n} / \mathrm{a}$ & [50] \\
\hline 3.78 & 1980 & $\mathrm{n} / \mathrm{a}$ & $\mathrm{n} / \mathrm{a}$ & 3060 & $\mathrm{n} / \mathrm{a}$ & $\mathrm{n} / \mathrm{a}$ & [56] \\
\hline $8.67 \pm 3.5$ & $7273 \pm 536$ & $3120.6 \pm 172$ & $\mathrm{n} / \mathrm{a}$ & $28.47 \pm 5$ & $112.2 \pm 24$ & $\mathrm{n} / \mathrm{a}$ & [51] \\
\hline $11.3 \pm 0.1$ & $3000 \pm 100$ & $\mathrm{n} / \mathrm{a}$ & $\mathrm{n} / \mathrm{a}$ & $50 \pm 3$ & $\mathrm{n} / \mathrm{a}$ & $\mathrm{n} / \mathrm{a}$ & [52] \\
\hline $3.9 \pm 0.1$ & $4321 \pm 21.2$ & $3200 \pm 77$ & $42,200 \pm 100$ & $2920.2 \pm 0.7$ & $\mathrm{n} / \mathrm{a}$ & $\mathrm{n} / \mathrm{a}$ & [53] \\
\hline $8.0 \pm 0.4$ & $5634 \pm 245$ & $2910 \pm 341$ & $10,560 \pm 978$ & $134 \pm 5.8$ & $\mathrm{n} / \mathrm{a}$ & $\mathrm{n} / \mathrm{a}$ & [54] \\
\hline $8.6 \pm 0.1$ & $12,560 \pm 1880$ & $4860 \pm 129$ & $18,250 \pm 1825$ & $\mathrm{n} / \mathrm{a}$ & $\mathrm{n} / \mathrm{a}$ & $\mathrm{n} / \mathrm{a}$ & [55] \\
\hline 3.17 & 1130 & $\mathrm{n} / \mathrm{a}$ & $\mathrm{n} / \mathrm{a}$ & 1640 & $\mathrm{n} / \mathrm{a}$ & $\mathrm{n} / \mathrm{a}$ & [57] \\
\hline 6.5 & 2530 & $\mathrm{n} / \mathrm{a}$ & 822 & 57 & 57 & $\mathrm{n} / \mathrm{a}$ & [58] \\
\hline 8.8 & 2780 & 1225 & $\mathrm{n} / \mathrm{a}$ & 8.2 & $\mathrm{n} / \mathrm{a}$ & $\mathrm{n} / \mathrm{a}$ & [59] \\
\hline $9.3-12.1$ & $1500 \pm 400$ & $\mathrm{n} / \mathrm{a}$ & $\mathrm{n} / \mathrm{a}$ & $360 \pm 110$ & $\mathrm{n} / \mathrm{a}$ & $\mathrm{n} / \mathrm{a}$ & [60] \\
\hline $8.7 \pm 0.2$ & $2412 \pm 145$ & $649.3 \pm 39.3$ & $2355 \pm 85$ & $8.11 \pm 4.86$ & $\mathrm{n} / \mathrm{a}$ & $\mathrm{n} / \mathrm{a}$ & [61] \\
\hline 9 & 17,600 & $\mathrm{n} / \mathrm{a}$ & 6900 & 120 & $\mathrm{n} / \mathrm{a}$ & 916 & [62] \\
\hline $4.0 \pm 0.12$ & $300 \pm 2.08$ & $250 \pm 1.62$ & $19.426 \pm 3.06$ & 25 & $\mathrm{n} / \mathrm{a}$ & $\mathrm{n} / \mathrm{a}$ & [63] \\
\hline 6.85 & 987 & 580 & 1185.4 & 12.4 & $\mathrm{n} / \mathrm{a}$ & $\mathrm{n} / \mathrm{a}$ & [64] \\
\hline 4.12 & 3280 & $\mathrm{n} / \mathrm{a}$ & $\mathrm{n} / \mathrm{a}$ & 147.4 & $\mathrm{n} / \mathrm{a}$ & $\mathrm{n} / \mathrm{a}$ & [74] \\
\hline
\end{tabular}

\section{Technologies for the Treatment of Tannery Wastewater}

The main technologies for the treatment of tannery wastewater focus only on certain parameters [75], as there is great difficulty in finding a treatment that completely reduces the pollutant load. Figure 2 presents a graphical description of the most common technologies. Since chromium is the main problem in this process, most treatments for these waters focus on the reduction and reuse of this element, followed by treatment for COD, BOD and TDS. These technologies include chemical coagulation processes [76,77] electrocoagulation [78], absorption, advanced oxidation processes [79] and biological processes such as phytoremediation $[13,14]$. 


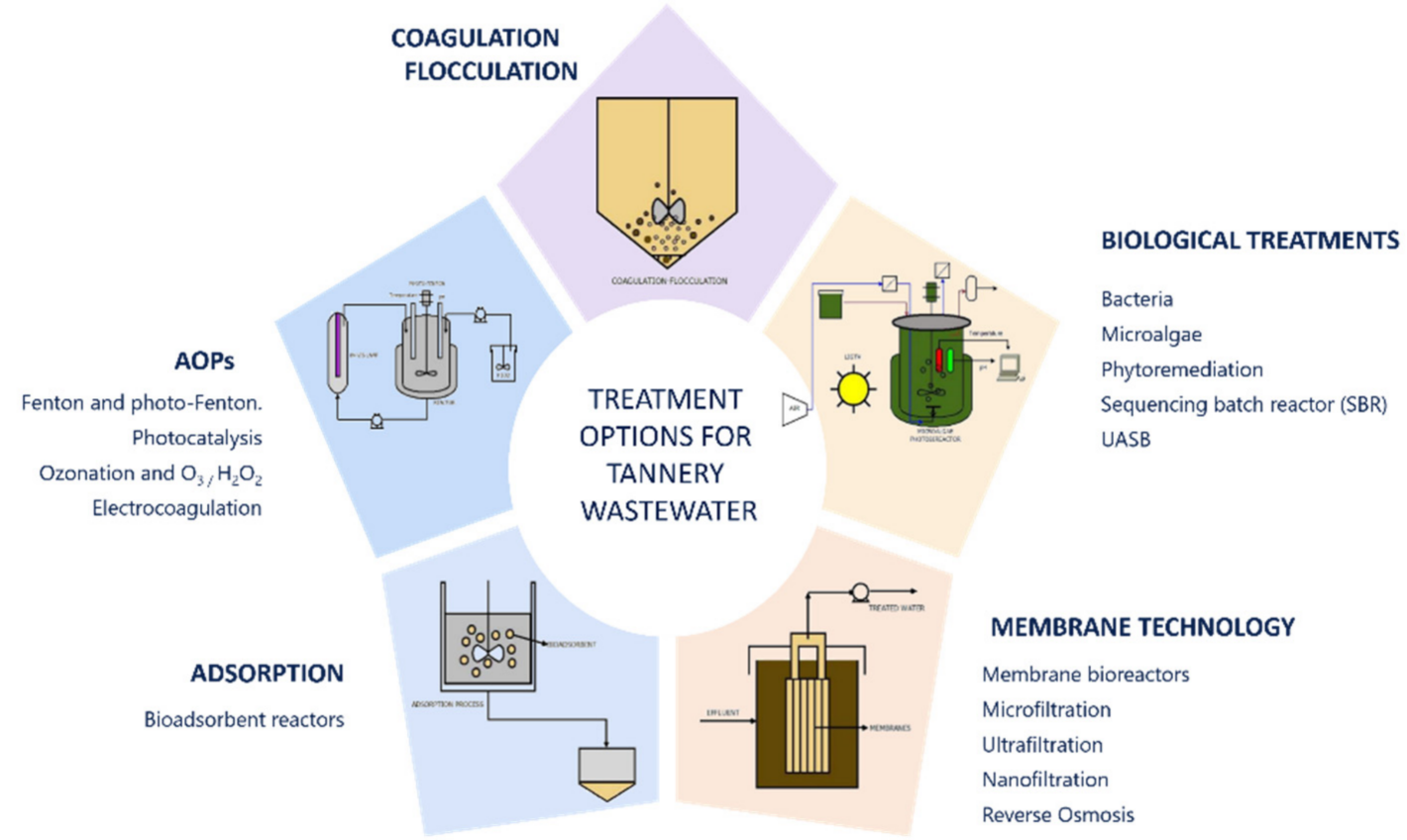

Figure 2. Treatment options for tannery wastewater.

\subsection{Coagulation}

Coagulation has been widely used due to its ease of operation; however, the generation of secondary waste from this process requires the greatest attention [6,78]. This method adds compounds such as aluminum sulfate and ferric chloride, which affect the removal of suspended solids, COD and chromium up to $46 \%, 37 \%$ and $99 \%$ at optimal concentrations of the coagulant and optimal $\mathrm{pH}$ ranges (7.5), respectively [78]. In addition, it works as a pretreatment method for tannery wastewater as it allows removing chromium and limiting its inhibitory effect on biological processes [79].

\subsection{Electrocoagulation}

Electrocoagulation is an electrochemical process that has the same principle as coagulation but reduces the formation of sludge typical of this process due to the fact that the coagulant is generated in situ by the oxidation reaction of an anode [80-82]. The use of mild steel electrodes as anodes under specific operating conditions has generated efficiencies of $82 \%, 90 \%$ and $96 \%$ for COD, sulfates and greases [83]. Some processes have implemented hybrid electrocoagulation and electrodialysis systems, showing greater efficiency to improve the quality of treated wastewater, obtaining removal percentages for COD, $\mathrm{NH}_{3}-\mathrm{N}$, chromium and color of $92 \%, 100 \%, 100 \%$ and $100 \%$ in processes with aluminum electrodes and $87 \%, 100 \%, 100 \%$ and $100 \%$ in processes with iron electrodes [84]. All these technologies improve the quality of the wastewater and allow the removal of polluting compounds; however, there are drawbacks with these treatment systems due to the high production of toxic sludge, the high operating cost and the complicated management of some of them, which are limited technologies in the developing countries [65]. This has led to the incursion of new technologies that are accessible and capable of mitigating environmental impacts, with advanced oxidation processes and biological processes being the main focus. This has allowed the development of research that shows excellent results when combining both processes, such as the synergy between biological treatments combined with electrooxidation [85] and, in other cases, with Fenton reagents [86].

In relation to the removal of $\mathrm{Cr}(\mathrm{VI})$, electrocoagulation has been implemented in recent years; in this process, flocculation occurs "in situ" due to the electrooxidation of a sacrificial anode (usually $\mathrm{Fe}$ or $\mathrm{Al}$ ) [87]. One of the advantages of this process compared to chemical coagulation lies in the sludge production; sludge reduction in electrocoagulation is $50 \%$ 
compared to chemical coagulation, showing more environmentally friendly properties. The process consists of transforming (directly or indirectly) $\mathrm{Cr}$ (VI) into $\mathrm{Cr}(\mathrm{III})$ and then precipitating and separating $\mathrm{Cr}(\mathrm{III})$ as a hydroxide [57]. Removal efficiency of $\mathrm{Cr}(\mathrm{VI})$ has been reported up to $99 \%$ in a $\mathrm{pH}$ range of 5 and 8 ; above this range, the removal efficiency decreases up to $27 \%$ while at the $\mathrm{pH}$ lower than $5,50 \%$ of $\mathrm{Cr}$ remains dissolved and the rest is electrodeposited in the sludge generated; therefore, the control of the $\mathrm{pH}$ of the solution is a variable that affects the process. It is known that chromium deposition is possible from solutions based on much less harmful $\mathrm{Cr}(\mathrm{III})$ compounds which are obtained by electrochemical processes. These electrolytes can be a real alternative; however, the electrochemical reactions that take place in the electrodeposition of chromium from $\mathrm{Cr}$ (III) salt solutions are complicated and their understanding still needs to be studied. In an electrodeposition process using electroplating, the removal of chromium ions from tannery wastewater was evaluated in a synthetic trivalent chromium solution; $96.5 \%$ of the total chromium content was removed in the untreated effluent [88]. Finally the route dictated by the thermodynamics of the multistep reduction of $\mathrm{Cr}$ (III) to $\mathrm{Cr}$ evidences that metallic chromium is probably deposited through the discharge of electroactive hydroxo complexes of bivalent chromium that form in the near-cathode layer due to the dissociation of water molecules $[89,90]$, but it is still necessary to evaluate this process more extensively in tannery wastewater.

\subsection{Advanced Oxidation Processes (AOPs)}

Advanced oxidation processes involve the production and application of highly oxidative radicals, primarily the free hydroxyl radical $(\mathrm{OH})$, capable of selectively degrading recalcitrant contaminants to a less harmful state. Figure 3 represents the most common advanced oxidation processes such as Fenton and photo-Fenton processes, ozone-based processes, photocatalysis, oxidation processes and hydrogen peroxide-UV processes, among other things $[8,50,91-94]$.

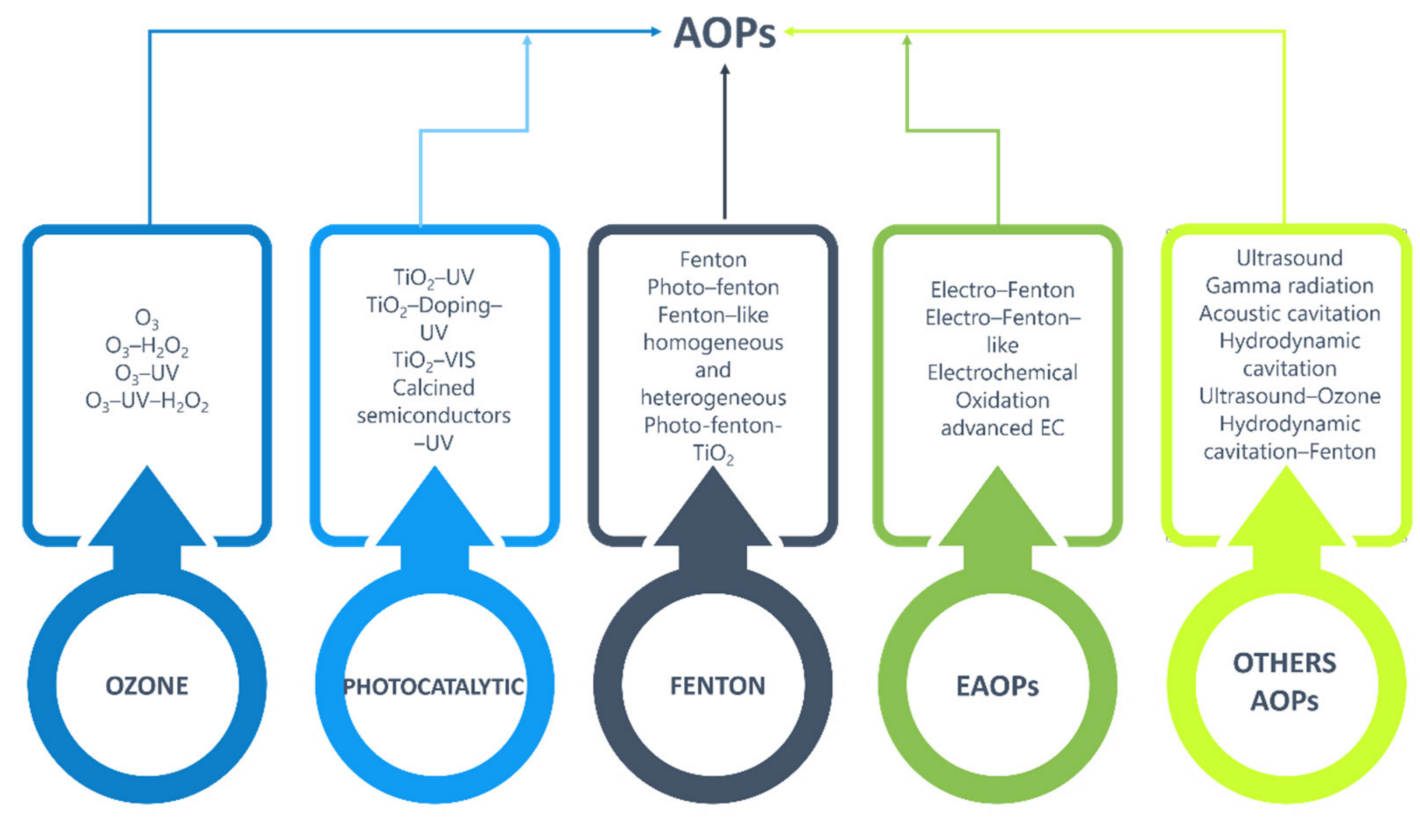

Figure 3. Types of oxidation processes used in the treatment of tannery wastewater.

Due to the ability to oxidize a wide range of micronutrients, these processes have been very useful in wastewater treatment; among the main ones is Fenton [95-98] which uses ferrous iron $\left(\mathrm{Fe}^{2+}\right)$ to decompose hydrogen peroxide and form an $\mathrm{OH}$ radical before reducing it again [99]; however, one of its main limitations is the disposition of large amounts of ferric ions in the mud, which can be overcome by using the reagent photo- 
Fenton which is a cyclical process and regenerates the $\mathrm{Fe}^{2+}$ ion $[91,100]$. The Fenton process has obtained important results in the treatment of tannery wastewater, 93\% COD, 98\% $\mathrm{BOD}$ and $62 \%$ chromium were removed when combined with a biological process using Thiobacillus ferrooxidans [86]. Another advanced oxidation method is ozone, which has been implemented in wastewater treatment due to its ability to reduce color, synthetic aromatic compounds and persistent organic pollutants (POPs) [101-105]. This process has not only demonstrated its effectiveness in pollutant removal, but also works well with biological degradation processes as the integrated treatment significantly improves performance [35,106].

Electrochemical processes have had great relevance in recent years [83,107]; this technology generates oxidizing agents, destroying organic compounds until their mineralization, using methods of anodic oxidation, photoelectrocatalysis $[108,109]$ and electroFenton [110-112]. This method allows the elimination of toxic compounds, nutrients and non-biodegradable organic compounds from tanneries with high levels of salinity and organic pollutants due to the implementation of different electrodes under the activity of direct and indirect oxidants [113]. Table 2 shows different AOPs used in the treatment of tannery wastewater.

Table 2. AOP in tannery wastewater.

\begin{tabular}{|c|c|c|c|c|}
\hline Process & Operating Conditions & Evaluated Parameters & Efficiency & Reference \\
\hline Cavitation & $\begin{array}{l}\text { The amount of energy dissipated } \\
\text { in } 250 \mathrm{~mL} \text { was } 0.122 \mathrm{~W}^{*} \mathrm{~mL}^{-1}\end{array}$ & COD & $87 \%$ & [50] \\
\hline \multirow[t]{3}{*}{ Fenton } & $\begin{array}{c}\text { V: } 50 \mathrm{~mL}, \mathrm{~T}: 25 \pm 0.1^{\circ} \mathrm{C} \text {, agitation: } \\
150 \mathrm{rpm}, \mathrm{FeSO}_{4}: 1-5 \mathrm{~g} \mathrm{~L}^{-1} \text {, time: } \\
\text { 5-300 min; } \mathrm{H}_{2} \mathrm{O}_{2} / \mathrm{COD} \text { ratio } \\
(w / w): 0.5-1.0\end{array}$ & COD & $58.4 \%$ & [95] \\
\hline & $\begin{array}{c}\text { V: } 500 \mathrm{~mL}, \mathrm{pH}: 3, \mathrm{~T}: 40-45^{\circ} \mathrm{C}, \\
\mathrm{H}_{2} \mathrm{O}_{2}: 0.15-0.6 \mathrm{~g} \mathrm{~L}^{-1}, \mathrm{FeSO}_{4}: \\
\text { 500-750 mg L } \\
\text {-1 , time: } 0-30 \mathrm{~min} .\end{array}$ & COD & $68 \%$ & [96] \\
\hline & $\begin{array}{l}\text { 3V: } 300 \mathrm{~mL} \text {, agitation: } 150 \mathrm{rpm}, \\
\text { time: } 60 \mathrm{~min} ; \mathrm{Fe}^{2+} \text { dosage: } \\
\text { 0-20 mg L L } \mathrm{pH}^{-1} 3-7, \mathrm{H}_{2} \mathrm{O}_{2} \\
\text { dosage: } 50-100 \mathrm{mg} \mathrm{L}^{-1}\end{array}$ & $\begin{array}{l}\text { COD } \\
\text { Color } \\
\text { Turbidity } \\
\text { Sludge }\end{array}$ & $\begin{array}{l}\text { COD: } 80 \% \\
\text { Color: } 90 \% \\
\text { Turbidity: } 95 \% \\
\text { Sludge: } 70 \%\end{array}$ & [98] \\
\hline $\begin{array}{l}\text { Fenton }+\mathrm{NaOCl} \text { and } \\
\text { Fenton }+\left(\mathrm{NH}_{4}\right)_{2} \mathrm{~S}_{2} \mathrm{O}_{8}\end{array}$ & $\begin{array}{c}\mathrm{V}: 100 \mathrm{~mL}, \mathrm{pH}: 3.5 \text {, agitation: } \\
200 \mathrm{rpm}, \mathrm{Fe}^{2+} \text { dosage: } 11.5 \mathrm{mg} / \mathrm{g} \\
\mathrm{DS}, \mathrm{H}_{2} \mathrm{O}_{2} \text { dosage: } 167.0 \mathrm{mg} / \mathrm{g} \text { DS, } \\
\text { time: } 12 \mathrm{~min} .\end{array}$ & $\mathrm{Cr}$ & $73.3 \%$ & [97] \\
\hline Photo-Fenton & $\begin{array}{c}\text { V: } 500 \mathrm{~mL} \text {, solar irradiation: } 5 \mathrm{~h} \text {; } \\
\mathrm{Fe}^{2+}: 0.4-0.5 \mathrm{~g} \mathrm{~L}^{-1} ; \mathrm{H}_{2} \mathrm{O}_{2}: \\
15-30 \mathrm{~g} \mathrm{~L}^{-1}, \mathrm{pH}: 3 \text {, time: } 2 \mathrm{~h}\end{array}$ & $\begin{array}{l}\text { COD } \\
\text { TDS }\end{array}$ & $\begin{array}{l}\text { COD: } 90 \% \\
\text { TSS: } 50 \%\end{array}$ & [100] \\
\hline \multirow[t]{3}{*}{ Ozone } & $\begin{array}{c}\mathrm{V}: 2500 \mathrm{~L} \text {, flow rate: } 2 \mathrm{~m}^{3} \mathrm{~h}^{-1} ; \mathrm{O}_{3} \\
\text { dosage: } 150 \mathrm{~g} \mathrm{~m}^{-3} \text {, time: } 60 \mathrm{~min} \text {, } \\
\text { pH: } 6.8 .\end{array}$ & $\begin{array}{l}\text { COD } \\
\text { TSS } \\
\text { TKN } \\
\text { Color }\end{array}$ & $\begin{array}{l}\text { COD: } 97 \% \\
\text { TSS: } 96 \% \\
\text { TKN: } 91 \% \\
\text { Color: } 96 \%\end{array}$ & [101] \\
\hline & $\begin{array}{c}\mathrm{V}: 5 \mathrm{~L}, \mathrm{pH}: 4-7-9, \mathrm{O}_{3} \text { dosage: } \\
1.6 \mathrm{mg} \mathrm{L}^{-1} \text {, time: } \\
10-20-30-40-50 \mathrm{~min} .\end{array}$ & Color & $\begin{array}{c}97 \% \text { in a time of } \\
20 \mathrm{~min} \text { and a } \mathrm{pH} \text { of } 7\end{array}$ & [102] \\
\hline & $\begin{array}{l}\mathrm{V}: 3 \mathrm{~L}, \mathrm{pH}: 3-6-9, \text { Ozone flow rate: } \\
1 \text { and } 8 \mathrm{~g} \mathrm{~h}^{-1} \text {. time: } \\
\text { 10-20-40-60-90-120 min, T: } 27^{\circ} \mathrm{C}\end{array}$ & COD & COD: $70 \%$ & [104] \\
\hline Fenton and Ozone & $\begin{array}{l}\text { V: } 0.5 \mathrm{~L}, \mathrm{Fe}^{2+} \text { concentration: } 120 \text { to } \\
300 \mathrm{mg} \mathrm{L}^{-1} \text {, concentration of } \\
\mathrm{H}_{2} \mathrm{O}_{2}: 600-2000 \mathrm{mg} \mathrm{L}^{-1}, \mathrm{pH}: 4 \\
\text { Ozone flow: } 1 \mathrm{~L} \mathrm{~min}^{-1} \text {. }\end{array}$ & COD & COD: $60-70 \%$ & [105] \\
\hline
\end{tabular}


Table 2. Cont.

\begin{tabular}{|c|c|c|c|c|}
\hline Process & Operating Conditions & Evaluated Parameters & Efficiency & Reference \\
\hline $\begin{array}{l}\text { Ozone coupled with } \\
\text { phycoremediation }\end{array}$ & $\begin{array}{l}\mathrm{V}: 1 \mathrm{~L}, \mathrm{pH}: 3.7-6-9, \text { ozone flow } \\
\text { rate: } 2-4-6 \mathrm{~g} \mathrm{~h}^{-1} \text {, time: } \\
10-20-40-60-90-120 \mathrm{~min} .\end{array}$ & $\begin{array}{l}\mathrm{COD}, \text { color, } \mathrm{Cr}, \mathrm{NH}_{4}, \\
\mathrm{PO}_{4}, \mathrm{TDS}\end{array}$ & $\begin{array}{c}\text { COD: } 84 \% \\
\text { Color: } 60 \% \\
\text { Cr: } 97 \% \\
\mathrm{NH}_{4}-\mathrm{N}: 82 \% \\
\mathrm{PO}_{4}-\mathrm{P}: 100 \% \\
\text { TDS: } 10 \%\end{array}$ & [43] \\
\hline \multirow[t]{2}{*}{ Electrochemical } & $\begin{array}{c}\text { V: } 2 \mathrm{~L} \text {, total surface area: } \\
427.84 \mathrm{~cm}^{2} ; \mathrm{pH}: 3-9 ; \text { salt } \\
\text { concentration: } 10-40 \mathrm{~g} \mathrm{~L}^{-1} \mathrm{NaCl} \text {; } \\
\text { time: } 120 \mathrm{~min} .\end{array}$ & COD & $\begin{array}{l}\text { COD: } 89 \% \text { to } \\
0.012 \mathrm{~A} \mathrm{~cm}{ }^{-2} \\
\text { pH: } 9 \text {, salt } \\
\text { concentration: } \\
30 \mathrm{~g}^{*} \mathrm{~L}^{-1} \mathrm{NaCl}\end{array}$ & [107] \\
\hline & $\begin{array}{l}\text { V: } 1.15 \mathrm{~L} \text {, total surface area: } \\
69.75 \mathrm{~cm}^{2}, \text { pH: } 2-11 \text {; current } \\
\text { density: } 3.5-70 \mathrm{~A} \mathrm{~cm}^{-2} \text {; time: } \\
\text { 10-70 min. }\end{array}$ & OD & $\begin{array}{l}\text { COD: } 62 \% \\
\text { in a range of } \mathrm{pH} 3-5 \\
\text { and time: } 10 \mathrm{~min}\end{array}$ & [83] \\
\hline \multirow[t]{3}{*}{$\begin{array}{l}\text { Electrochemical/photo- } \\
\text { Fenton/Fenton }\end{array}$} & $\begin{array}{l}\text { V: } 1.5 \mathrm{~L}, \mathrm{pH} 8.3 \text {; current density: } \\
68 \mathrm{~mA} \mathrm{~cm}{ }^{-2} \text {; currents and } \\
\text { voltages: } 0-10 \mathrm{~A} \text { and } 0-30 \mathrm{~V} ; \mathrm{t} \text { : } \\
\text { 5-60 min. }\end{array}$ & COD, color, turbidity & $\begin{array}{l}\text { COD: } 99 \% \\
\text { Turbidity: } 98 \% \\
\text { TSS: } 65 \%\end{array}$ & [103] \\
\hline & $\begin{array}{l}\text { V: } 4 \mathrm{~L}, \mathrm{pH}: 3 \text {; anode and cathode } \\
\text { electrode area: } 64 \mathrm{~cm}^{2} \text {; time: } \\
180 \mathrm{~min} .\end{array}$ & COD, color & $\begin{array}{l}\text { COD: } 90 \% \\
\text { Color: } 86 \%\end{array}$ & [108] \\
\hline & $\begin{array}{l}\text { V: } 500 \mathrm{~mL}, \mathrm{pH}: 3.0, \mathrm{H}_{2} \mathrm{O}_{2} \\
\text { concentration: } 0.5 \mathrm{Mm} ; \mathrm{Fe}^{2+} \\
\text { concentration: } 0.50 \mathrm{mM} .\end{array}$ & COD, color & $\begin{array}{l}\text { Color: } 97 \% \\
\text { COD: } 95 \%\end{array}$ & [109] \\
\hline $\begin{array}{l}\text { Electrocoagulation } \\
\text { combined with } \\
\text { photoreactor UVC }\end{array}$ & $\begin{array}{l}\text { V: } 0.2 \mathrm{~L} \text {, UV lamp wavelength: } \\
254 \mathrm{~nm} \text { and } 185 \mathrm{~nm} \text {; electric } \\
\text { current: } 100-600 \mathrm{~mA} \text {; time: } \\
\text { 10-30 min. }\end{array}$ & $\mathrm{COD}, \mathrm{Cr}$ & $\begin{array}{l}\text { COD: } 99.52 \% \\
\text { Cr: } 98.27 \%\end{array}$ & [110] \\
\hline \multirow[t]{2}{*}{ Photocatalysis } & $\begin{array}{c}\text { Air flow: } 140 \mathrm{~N} \mathrm{~cm}^{3} \mathrm{~min}^{-1} \text {; four } \\
\text { UV lamps: power: } 8 \mathrm{~W} \text {, } \\
\text { wavelength: } 350 \mathrm{~nm} \text {; photon flux: } \\
25 \mathrm{~mW} / \mathrm{cm}^{2} \text {. }\end{array}$ & COD & $\begin{array}{c}\text { The } \mathrm{ZnO} \text { _ac1 } \\
\text { photocatalyst } \\
\text { achieved a COD } \\
\text { removal } \\
\text { of } 70 \% \text { in } 180 \text { min of } \\
\text { irradiation }\end{array}$ & [111] \\
\hline & $\begin{array}{c}\mathrm{V}: 5 \mathrm{~L} \text {; without } \mathrm{pH} \text { adjustment; } \\
\text { time: } 5 \mathrm{~h} \text { in PTR; exposed directly } \\
\text { to sunlight. }\end{array}$ & $\mathrm{COD}, \mathrm{Cr}$ & $\begin{array}{c}\text { COD: } 82.26 \% \\
\text { Cr: } 76.48 \%\end{array}$ & [112] \\
\hline
\end{tabular}

In AOPs, the reaction of $\mathrm{OH}$ and the various pollutants present in tannery effluents results in mineral end products that produce inorganic ions and carbon dioxide $[114,115]$. The efficiency of each process depends on the physicochemical characteristics of the pollutants present in tannery effluents, as well as on the generation of hydroxyl radicals. The generation of these radicals can be achieved by different processes. Ozone is a technology that has been reported in the treatment of dyeing water, reaching removals of $90-98 \%$ COD and $96 \%$ color $[104,105]$; the efficiency of the process depends largely on $\mathrm{pH}$; at acidic values $<4.5$, the reaction is direct, molecular ozone dominates the reaction being selective mainly in the destruction of chromophore groups, while at the $\mathrm{pH}>7$, ozone decomposes, generating $\mathrm{OH}$ which is less selective and has a higher oxidation potential; the ozone flow rate is another important variable, the percentage of removal is directly proportional to the ozone flow rate with respect to time; increasing the ozone rate increases the removal efficiency. It has been reported that excess ozone can lead to the formation of residual 
$\mathrm{H}_{2} \mathrm{O}_{2}$, allowing the wastewater concentration to be increased so that the COD present can be degraded by the excess $\mathrm{H}_{2} \mathrm{O}_{2}$ [114].

In relation to photocatalytic processes, photo-Fenton is one of the most studied in tannery effluents, and has achieved removals of 70-90 \% COD, 86-98\% color [100,111] and $90 \% \mathrm{Cr}$ [114]; the efficiency of the process depends largely on the $\mathrm{pH}$ of the solution, the optimal range of higher catalytic activity is $2.8-3.0, \mathrm{pH}$ values $>5$ generate ferric hydroxides that reduce the reactivity of $\mathrm{OH}$, while at values below 2 , complex iron species are formed that react more slowly with $\mathrm{H}_{2} \mathrm{O}_{2}$, decreasing the efficiency of the process [116]; the amount of ferrous ions generated also affects the process; excess concentrations in the solution can generate precipitates, increasing the TDS concentration [117]. Finally, the irradiation time is another variable that affects the process; this should be as low as possible to minimize energy consumption without affecting process efficiency. The $\mathrm{UV} / \mathrm{H}_{2} \mathrm{O}_{2}$ system has great relevance in the treatment of tannery effluents, the main reason being the absence of sludge production and significant COD removal in very short reaction times [118].

The effectiveness of the $\mathrm{UV} / \mathrm{H}_{2} \mathrm{O}_{2}$ process for the degradation of complex compounds present in these effluents depends on several factors. The $\mathrm{pH}$ affects the reactivity of $\mathrm{H}_{2} \mathrm{O}_{2}$ as well as the generation of the $\mathrm{OH}$ radical, therefore, a $\mathrm{pH}$ of 3-5 is recommended to implement the $\mathrm{UV} / \mathrm{H}_{2} \mathrm{O}_{2}$ process. The type of the UV lamp is another important variable in this process; the selection of the waves generated by the lamp is a design parameter that defines the efficiency of the system. The medium-pressure ultraviolet lamp (MP-UV) and the low-pressure ultraviolet lamp (LP-UV) are the two types of lamps used in the UV $/ \mathrm{H}_{2} \mathrm{O}_{2}$ system. The MP-UV lamp is usually the most widely used as it is capable of emitting a broad spectrum of waves much faster than the LP-UV lamp, allowing a rapid dissociation of peroxide radicals resulting in a direct photolysis that allows a faster degradation of the pollutants present in tannery effluents [110]. Temperature is an important factor in the $\mathrm{UV} / \mathrm{H}_{2} \mathrm{O}_{2}$ system; at room temperature, the reaction of the peroxide with the pollutants present in the tannery effluents is lower, hence, it is required to accelerate the process by increasing the temperature $\left(40^{\circ} \mathrm{C}\right.$ and $60^{\circ} \mathrm{C}$ ), allowing the generation of $\mathrm{OH}$ from $\mathrm{H}_{2} \mathrm{O}_{2}$ and increasing the reactivity of these radicals towards pollutants [119].

Cavitation is a phenomenon that results in the generation of highly reactive free radicals, releasing large amounts of energy and creating intense turbulence in the liquid. Depending on the cavitation mode, four different forms are distinguished: acoustic cavitation, hydrodynamic cavitation, cavitation, optical cavitation and particle cavitation. It has been reported that acoustic cavitation and hydrodynamic cavitation have proven to be effective techniques for the treatment of tannery effluents $[114,120]$. The process parameters that affect acoustic cavitation are as follows: ultrasonic power; since the amount of $\mathrm{OH}$ generation and the energy dissipated depend on the ultrasonic power and the immersion depth of the probe, it is essential that the immersion depth of the probe is adequate for the propagation and dissipation of the wave. As for hydrodynamic cavitation, factors such as $\mathrm{pH}$, temperature and inlet pressure affect the removal efficiency of parameters such as COD and color [121].

\section{Energy and Cost Considerations in AOPs}

The selection of an AOP for wastewater treatment is not only based on the removal efficiency, although it is important, the energy consumption or efficiency of an AOP has taken great relevance when selecting a process. The electrical energy per order (EEO) is an indicator used to determine energy efficiency [122], defined as the amount of $\mathrm{kWh}$ required to reduce the concentration of a pollutant by an order of magnitude in a given volume of treated wastewater $\left(\mathrm{kWh} \mathrm{m}^{-3} \log ^{-1}\right)$ [123]. This parameter has been used to analyze and compare different AOPs in the treatment of pollutants present in wastewater; the reported EEO values are in the range of $0.1-15 \mathrm{kWh} \mathrm{m}^{-3} \log ^{-1}$ for processes such as ozonation, $\mathrm{UV} / \mathrm{O}_{3}, \mathrm{UV} / \mathrm{H}_{2} \mathrm{O}_{2}, \mathrm{~EB}$, photo-Fenton, $\mathrm{O}_{3} / \mathrm{H}_{2} \mathrm{O}_{2}$; some processes such as $\mathrm{UV} /$ catalyst, microwave and ultrasound report high values in the range of $150-8000 \mathrm{kWh} \mathrm{m}^{-3} \log ^{-1}$ [124]. 
The EEO value varies in relation to the process efficiency: the higher the process efficiency, the lower the calculated EEO value.

Another aspect that affects the EEO value is related to the characteristics of the wastewater and the types of pollutants present; a very complex wastewater matrix with several pollutants will obtain higher EEO values compared to simple matrices or wastewaters with only one pollutant [121]. Wardenier et al. [125] conducted an investigation comparing UV, $\mathrm{O}_{3}$ and $\mathrm{H}_{2} \mathrm{O}_{2}$ efficiency for the treatment of micropollutants such as atrazine, alachlor and bisphenol and found that energy consumption and treatment cost were in the following order: $\mathrm{UV}>\mathrm{UV} / \mathrm{H}_{2} \mathrm{O}_{2}>\mathrm{UV} / \mathrm{O}_{3}>\mathrm{UV} / \mathrm{O}_{3} / \mathrm{H}_{2} \mathrm{O}>\mathrm{O}_{3} / \mathrm{H}_{2} \mathrm{O}_{2}>\mathrm{O}_{3}$, while the order in relation to removal efficiency was $\mathrm{O}_{3} / \mathrm{H}_{2} \mathrm{O}_{2}>\mathrm{UV} / \mathrm{O}_{3} / \mathrm{H}_{2} \mathrm{O}_{2}>\mathrm{UV} / \mathrm{O}_{3}>\mathrm{UV} / \mathrm{H}_{2} \mathrm{O}_{2}>$ $\mathrm{UV} / \mathrm{H}_{2} \mathrm{O}_{2}>\mathrm{O}_{3}>\mathrm{UV}$. In an azo dye treatment process, when implementing ultrasound with AOPs to achieve $90 \%$ removal, the order in relation to cost and energy consumption was as follows: $\mathrm{US}>$ photocatalysis $>\mathrm{UV}>\mathrm{UV} / \mathrm{H}_{2} \mathrm{O}_{2}>\mathrm{UV} / \mathrm{O}_{3}>$ photo-Fenton $>\mathrm{O}_{3}$; in relation to the percentage of removal, the order was as follows: photocatalysis $>$ photo-Fenton $>\mathrm{UV} / \mathrm{H}_{2} \mathrm{O}_{2}>\mathrm{O}_{3}$ [125]. Performing these calculations and comparing by technology provides information for process scale-up as well as for sustainability analysis [126-130]. Table 3 shows a comparison in terms of energy consumption and cost of different AOPs.

Table 3. Energy consumption and costs of different AOPs.

\begin{tabular}{|c|c|c|c|c|}
\hline AOP Type & $\begin{array}{c}\text { EEO } \\
\left(\mathrm{kWh} \mathrm{m}^{-3} \text { Order }^{-1}\right)\end{array}$ & $\begin{array}{c}\text { EEM } \\
\left(\mathrm{kWh}^{-1}\right)\end{array}$ & $\begin{array}{c}\text { Cost } \\
\left(\mathrm{US} \$ \mathrm{~m}^{-3}\right)\end{array}$ & References \\
\hline $\mathrm{O}_{3}$ & 0.3 & 495 & 11.3 & \multirow{10}{*}[114,122,124-130]{} \\
\hline $\mathrm{O}_{3} / \mathrm{H}_{2} \mathrm{O}_{2}$ & 0.2 & - & 8.6 & \\
\hline $\mathrm{UV} / \mathrm{O}_{3}$ & 225.25 & 111.56 & 6 & \\
\hline Photo-Fenton & 12 & - & 64.13 & \\
\hline Photoelectro-Fenton & 132.6 & 0.125 & $8.4-66.22$ & \\
\hline Electro-Fenton (EF) & 127.2 & 0.235 & 8.48 & \\
\hline $\mathrm{UV} / \mathrm{US} / \mathrm{H}_{2} \mathrm{O}_{2}$ & 39.76 & 167 & 4.49 & \\
\hline Ultrasound & $800-8000$ & 11,993 & 55.14 & \\
\hline Photocatalysis & 3654.68 & $21,129.15$ & 2.8 & \\
\hline Electrocoagulation & 59.4 & 0.060 & 3.94 & \\
\hline
\end{tabular}

\subsection{Biotechnological Conversion of Tannery Wastewater}

Currently, the capacity of biological processes in wastewater treatment has been demonstrated to be more environmentally friendly for the elimination of organic compounds and micropollutants compared to other technologies [131]. However, the high concentration of pollutants makes these treatments difficult to implement since the levels of toxicity and the impacts generated on the cells make their control and the adaptation of the species to this process complicated. These difficulties have been overcome in recent years, where different microorganisms have been proposed as an efficient alternative and an opportunity to establish bioremediation centers and economic biorefineries to recover resources and promote sustainable economic development for the treatment of wastewater and the removal of heavy metals from water [131,132]. Studies on these processes use biological agents such as bacteria, microalgae and some fungi, among others [7,133].

\subsubsection{Bacteria}

Within the biotechnological processes implemented for the treatment of tannery wastewater, the use of chromium-resistant bacteria has been reported as an economical and ecological alternative for the detoxification and bioremediation of these effluents due to the ability to adapt to exposure stress, developing various mechanisms of resistance and adaptation [132]. One of the processes that have been implemented is the batch reactor systems (SBR) combined with respirometry; the decrease in COD concentration by $74-88 \%$ has been reported in 12- and $24-\mathrm{h}$ operating cycles, which is more efficient than when continuous aerobic systems are used; however, to improve the removal of 
the remaining COD fraction, the development of more ecological chemical products for tanning is suggested [134]. On the other hand, in activated sludge systems [135], positive results are shown in the removal of $\mathrm{BOD}_{5}$ and $\mathrm{COD}$, of $90 \%$ and $80 \%$, respectively, with specific operation requirements in suspended solids of mixed liquor (MLVSS) of $3500 \mathrm{mg} / \mathrm{L}$ maintaining aeration time of $12 \mathrm{~h}$ [136]. In treatment systems with plants, pilot-scale experiments of tannery waters from south of Bogotá (Colombia) have been developed through the use of Eichhornia crassipes; the use of wastewater occurred in proportions of $40 \%$ wastewater $/ 60 \%$ distilled water, and $60 \%$ tannery water $/ 40 \%$ distilled water, with initial chromium values of $7480 \mathrm{mg} / \mathrm{L}$ and $12,200 \mathrm{mg} / \mathrm{L}$, respectively, obtaining chromium removal of $61 \%$ and $51 \%$, although the results are not significant. The discharge standard was met due to the high initial amount of chromium [32].

The use of different species of bacteria has been reported with the ability to degrade tannery wastewater. It has been found that different species of Bacillus such as Bacillus sp. [137], Bacillus flexus [138], Bacillus aquimaris [54], Bacillus cereus [139] and Bacillus subtilis [140] can remove up to $85 \%$ COD and $54-95 \% \mathrm{Cr}$ present in these effluents. In relation to species of the genus Pseudomonas, it has been reported that P. aeruginosa $[54,139]$ and P. putida [141] can remove up to $98 \%$ COD and $93 \%$ Cr. Species of the genus Halomonas, H. maura, H. pacifica [142] and Halomonas sp. [143], have been found to remove COD in the range of 76-96\%. Desulfovibrio desulfuricans species [144], Desulfovibrio sp. [145], with the ability to remove up to $65 \% \mathrm{Cr}$ and $85 \% \mathrm{COD}$ has been reported. Microbacterium arborescens species [54] $M$. testaceum [146] can remove up to $68.4 \%$ COD and $99 \% \mathrm{Cr}$. Different enterobacteria have been reported for the biotreatment of tannery wastewater, Enterobacter sp. [54], Serratia marcescens [147] and E. coli [148]; they have the ability to remove up to $63 \%$ COD and up to $54 \%$ Cr. The groups of nitrifying bacteria [149] and denitrifying bacteria [150] have also been reported in the treatment of these effluents, reaching removal percentages of $80 \% \mathrm{COD}$ and $64.4 \% \mathrm{Cr}$ and $98.3 \% \mathrm{COD}$ and $88.5 \% \mathrm{Cr}$, respectively. Other microorganisms have been found with the ability to treat tannery effluents: Shewanella xiamenensis [151] has exhibited an ability to remove $80 \%$ COD and $73 \% \mathrm{Cr}$; Acidithiobacillus thiooxidans [152] achieved removal of 95\% Cr, while species of Cellulosimicrobium [37] have achieved removal of $99.3 \%$. All this has led to the bioprospecting of new species that allow better results.

\subsubsection{Utilizing Tannery Wastewater in Microbial Fuel Cells}

Chromium exists in various oxidation states, and, among them, $\mathrm{Cr}(\mathrm{VI})$ is considered pollution with a high degree of toxicity [153]. The process of removing $\mathrm{Cr}$ in wastewater such as tannery wastewater is energy-intensive [154]; therefore, current studies have focused on seeking to add value to this process to mitigate the high cost of this treatment [155-157]. One of the technologies that has gained great relevance is the microbial fuel cell (MFC); this process is an interstate alternative for the treatment of $\mathrm{Cr}(\mathrm{VI})$, in which $\mathrm{Cr}(\mathrm{VI})$ is reduced in the MFC through bacterial activity [158], which results in the generation of electricity, offsetting the cost of the treatment process [159-161]. MFCs are devices that use microorganisms, mainly bacteria, as catalysts to oxidize organic or inorganic matter and generate electricity. Electron acceptors in the cathode compartment play an important role in the performance of MFCs; oxygen and ferricyanide are the most commonly used ones, although recently the use of some pollutants with high electrochemical redox potentials that are present in wastewater as electron acceptors has been reported in MFCs while reducing at the same time [162-164]. An important aspect for the efficiency of the system lies in the design of a MFC; this is a key factor in the synthesis and production of electricity to obtain high efficiency and reduce costs for industrial applications. Some of the advantages of the MFC technology over other conventional systems are higher conversion efficiency than enzymatic fuel cells, sustainability of the process due to the efficiency of electricity conversion from the chemical energy of the substrate used [164,165], high efficiency in effluents with a low concentration of the organic pollutant load, low 
solids generation, adaptability to ambient temperatures, among other things [166-168].

Table 4 shows the different microorganisms used in MFC processes.

Table 4. Different microorganisms used in MFC processes.

\begin{tabular}{|c|c|c|c|}
\hline Microorganism & Removal Efficiency & MFC Performance & Reference \\
\hline Bacillus sp. & COD: $88 \%$ & $120 \mathrm{~mA} / \mathrm{m}^{2}$ and $7 \mathrm{~mW} / \mathrm{m}^{2}$ & [155] \\
\hline $\begin{array}{l}\text { Anaerobic microbial } \\
\text { consortium }\end{array}$ & COD: $48.5 \%$ & 44.2 and $52.1 \mathrm{~mW} / \mathrm{m}^{2}$ & [156] \\
\hline $\begin{array}{l}\text { Chlorococcum sp. } \\
\text { Synechococcus sp. }\end{array}$ & $\begin{array}{c}\text { COD: } \\
\text { 73.5\% (Chlorococcum sp.) } \\
69.4 \% \text { (Synechococcus sp.) }\end{array}$ & $\begin{array}{c}\text { Chlorococcum sp.: } \\
32.1 \pm 0.5 \text { and } 27.2 \pm 0.5 \mathrm{~mW} / \mathrm{m}^{2} \\
\text { Synechococcus sp.: } \\
42.5 \pm 0.5 \text { and } 37.2 \pm 0.3 \mathrm{~mW} / \mathrm{m}^{2}\end{array}$ & [157] \\
\hline Activated sludge consortium & $\begin{array}{l}\mathrm{NO}_{3}{ }^{-}: 87 \% \\
\mathrm{COD}: 90 \%\end{array}$ & $0.35 \mathrm{~mA} \cdot \mathrm{cm}^{-2}$ and power level of $6.11 \mathrm{~mW}$ & {$[159]$} \\
\hline Anaerobic sludge & COD: $98 \%$ & $88 \mathrm{~mW} / \mathrm{m}^{2}$ and $408 \mathrm{~mA}^{*} \mathrm{~m}^{-2}$ & [160] \\
\hline $\begin{array}{l}\text { Shewanella decolorationis S12, } \\
\text { Klebsiella pneumoniae L17 }\end{array}$ & COD: $42.5 \%$ & $\begin{array}{l}52.1 \mathrm{~mW} / \mathrm{cm}^{2} \text { with an air bubbling cathode } \\
6.8 \mathrm{~mW} / \mathrm{cm}^{2} \text { with a nitrogen bubbling cathode }\end{array}$ & [161] \\
\hline Algae biomass & $\begin{array}{l}\text { COD: } 72-95 \% \\
\text { Cr: } 98 \%\end{array}$ & $221 \mathrm{mV}$ to $760 \mathrm{mV}$ & [162] \\
\hline $\begin{array}{l}\text { Anaerobic microbial } \\
\text { consortium }\end{array}$ & $\mathrm{Cr}^{6+}: 95 \%$ & $89 \pm 3 \mathrm{~mW} / \mathrm{m}^{2}$ & [163] \\
\hline $\begin{array}{l}\text { Adapted microbial } \\
\text { consortium }\end{array}$ & Cr: $71.4 \%$ & $970.2 \pm 20.6 \mathrm{~mW} / \mathrm{m}^{2}$ & [167] \\
\hline $\begin{array}{l}\text { Trichococcus pasteurii } \\
\text { Pseudomonas aeruginosa }\end{array}$ & COD: $98 \%$ & $55.5 \mathrm{~mW} / \mathrm{m}^{2}$ & [168] \\
\hline
\end{tabular}

\subsubsection{Microalgae}

Microalgae are autotrophic and photosynthetic aquatic microorganisms capable of synthesizing various high-value compounds, such as lipids, proteins, carbohydrates and pigments, which, together with a rapid growth rate and the ability to adapt to extreme environments, make them a viable option in the wastewater treatment $[7,16,169,170]$. This adaptive capacity allows them to grow under various conditions of acidic $\mathrm{pH}$, high temperatures or excess of some compounds [171], allowing them to generate a greater amount of biomass and products of commercial interest [172,173]. Among the main pollutants in wastewater are organic compounds, nutrients and $\mathrm{CO}_{2}$; microalgae have the ability to assimilate some of these compounds for their metabolism (nitrogen, phosphorus, carbon, heavy metals, among other things), reducing the pollutant load of the water and minimizing eutrophication in water bodies [174], achieving efficient removal of up to $100 \%$ in some compounds. The main microalgae implemented in these treatment processes are Chlorella sp. [175], Scenedesmus sp. [176] and Dunaliella salina [177], among others. The ability of microalgae to use compounds present in wastewater reducing the pollutant load, strengthening the formation of metabolites and generating considerable amounts of oxygen that allow the proliferation of other microorganisms that contribute to the improvement of water quality makes them an interesting tool in wastewater treatment [178-181]. The adaptive capacity of microalgae, together with their ability to bioaccumulate heavy metals, allows them to be used as a potential system in the treatment of tannery wastewater. Table 5 shows different microalgae used in the treatment of tannery wastewater. It has been shown that this tolerant mechanism in Chlorella and Scenedesmus strains is due to the activation of antioxidant enzymes (superoxide dismutase, catalase and ascorbate peroxidase) as a biological response to oxidative damage induced by the presence of metals [182]. However, it is not yet possible to use the crude tannery effluent as a culture medium, which can be attributed to high toxic loads and the dark color of the crude effluent, which prevents the entry of light into the medium and limits the growth of microalgae, which suggests the application of wastewater dilutions to allow better adaptation $[16,183]$ and determination of the appropriate photoperiod [7]. 
The contents of other compounds present in the wastewater are also influential in the efficiency of chromium removal since they compete for the interaction with the functional groups of the microalgae, showing that in synthetic wastewater with significant concentrations of chromium $(20 \mathrm{mg} / \mathrm{L})$, there is greater efficiency than in tannery wastewater, the interaction of $\mathrm{pH}$, chromium concentration, strain used and temperature also playing an important role $[43,184]$. Chlorella strains have been extensively studied [182,184], exhibiting optimal growth in tannery wastewater diluted to 50\%, guaranteeing the phycoremediation of heavy metals of up to $73.1 \%, 90.4 \%, 92.1$ and $81.2 \%$ for $\mathrm{Cr}, \mathrm{Cu}, \mathrm{Pb}$ and $\mathrm{Zn}$, respectively, contributing to the accumulation of a high yield of lipids (by 18.5\%) and unsaturated fatty acids (by 50.05\%) [185]. Likewise, studies with C. vulgaris also showed significant removals of DQO, $\mathrm{NO}_{3}-\mathrm{N}, \mathrm{PO}_{4}-\mathrm{P}, \mathrm{SO}_{4}-\mathrm{S}$ and $\mathrm{Cr}$ of $94.74 \%, 100 \%, 91.73 \%, 99 \%$ and $100 \%$, respectively, between the 6 th and the 21th days of culture [42]. In strains of $C$. vulgaris and Pseudochlorella pringsheimii, significant reductions in the concentration of contaminants were observed, greater than $65 \%$ for $\mathrm{NH}_{3}-\mathrm{N}, 100 \%$ for $\mathrm{PO}_{4}-\mathrm{P}$, greater than $63 \%$ for COD and greater than $80 \%$ for total chromium, in dilutions of up to $30 \%$ of the residual water (6.25 mg/L of chromium); in addition, lipid accumulation of up to $25.4 \%$ was observed for Pseudochlorella and 9.3\% for Chlorella vulgaris in a 20\% dilution [43]. Da Fontoura et al. [186] reported positive results in strains of Scenedesmus using a central compound design, demonstrating that the concentration of wastewater and the intensity of light influence the amount of biomass produced and the removal of nitrogen and phosphorus. In this study, concentrations between $20 \%$ and $100 \%$ of the residual water were implemented, and removals of up to $85.631 \%$ were found for ammonia nitrogen, $96.78 \%$ for phosphorus and $80.33 \%$ for COD [13]. Ballén-Segura et al. [170] reported removal results for $\mathrm{Cr}(\mathrm{VI})$ greater than 98\%, for nitrates-greater than $90 \%$, for phosphates-greater than $99 \%$ and for BOD-greater than $88 \%$ (in similar concentrations). Regarding the concentration of heavy metals, efficiencies of 97\%, 95\%, 97\% and 97\% were found for $\mathrm{Cr}, \mathrm{Cu}, \mathrm{Pb}$ and $\mathrm{Zn}$ in dilutions of $10 \%$ of wastewater and of $57 \%, 79 \%, 48 \%$ and $65 \%$ for $\mathrm{Cr}, \mathrm{Cu}, \mathrm{Pb}$ and $\mathrm{Zn}$, respectively, in the $100 \%$ residual water concentration. Other authors $[2,12,30,170]$ have reported the ability of the genus Scendesmus to remove the organic pollutant load, COD-up to 97\%, and $\mathrm{Cr}$ - up to $98 \%$, present in tannery effluents. The genus Tetraselmis has also been reported in the treatment of tannery wastewater $[7,16]$, reaching removals of $54 \%$ for COD, $97 \%$ for nitrogen compounds and $97 \%$ for phosphorus compounds.

Table 5. Algal strains used in the treatment of tannery wastewater.

\begin{tabular}{|c|c|c|c|c|}
\hline Strain & Operating Conditions & Parameters & Removal Efficiency & Reference \\
\hline Scenedesmus sp. & $\begin{array}{l}\text { V: } 1 \mathrm{~L} ; w / w \text { concentration: } \\
\text { 20-100\%; light intensity: } \\
97.5-182.5 \mu \mathrm{mol} \text { photons } \mathrm{m}^{-2} \mathrm{~s}^{-1} \text {; } \\
\text { pH: } 7.5 ; \mathrm{T}: 25^{\circ} \mathrm{C} \text {; time: } 25 \mathrm{~d} \text {. }\end{array}$ & $\begin{array}{l}\mathrm{COD} \\
\mathrm{NH}_{3}-\mathrm{N} \\
\mathrm{PO}_{4}-\mathrm{P}\end{array}$ & $\begin{array}{l}\mathrm{COD}: 80.33 \% \\
\mathrm{NH}_{3}-\mathrm{N}: 85.63 \% \\
\mathrm{PO}_{4}-\mathrm{P}: 96.78 \%\end{array}$ & [185] \\
\hline Scenedesmus sp. & $\begin{array}{l}\text { V: } 3 \mathrm{~L} ; \mathrm{pH}: 2-11, \mathrm{~T}: 25-40{ }^{\circ} \mathrm{C} \text {; dye } \\
\text { concentration: } 200-1500 \mathrm{mg} \mathrm{L}^{-1} \text {; } \\
\text { contact time: } 540 \mathrm{~min} .\end{array}$ & $\begin{array}{c}\text { Absorption of the } \\
\text { AB-161 dye } \\
\text { pH } \\
\text { TOC } \\
\text { Total nitrogen (TN) }\end{array}$ & $\begin{array}{c}\text { AB-161: } 69.83 \% \\
\text { TOC: } 50.78 \% \\
\text { TN: } 19.80 \%\end{array}$ & [13] \\
\hline Nannochloropsis oculata & $\begin{array}{l}\text { V: } 0.2 \mathrm{~L} \text {; light intensity: } 75 \mu \mathrm{mol} \\
\text { photons } \mathrm{m}^{-2} \mathrm{~s}^{-1} \text {; photoperiod: } \\
\text { 12:12; T: } 25^{\circ} \mathrm{C} \text {; time: } 15 \mathrm{~d} \text {; pH: } 7.6 .\end{array}$ & $\begin{array}{c}\mathrm{COD} \\
\text { Color } \\
\text { Inorganic carbon } \\
\mathrm{NH}_{4}-\mathrm{N} \\
\mathrm{PO}_{4}-\mathrm{P} \\
\text { Chromium }(\mathrm{Cr}) \\
\text { TDS }\end{array}$ & $\begin{array}{c}\text { COD: } 84 \% \\
\text { Color: } 60 \% \\
\text { Inorganic carbon: } 90 \% \\
\mathrm{NH}_{4}-\mathrm{N}: 82 \% \\
\mathrm{PO}_{4}-\mathrm{P}: 100 \% \\
\text { Cr: } 97 \% \\
\text { TDS: } 10 \%\end{array}$ & [43] \\
\hline Dunaliella salina & $\begin{array}{l}\mathrm{V}: 0.25 \mathrm{~L} ; \mathrm{T}: 25^{\circ} \mathrm{C} ; \mathrm{pH}: 7.5 ; \mathrm{Cr}(10, \\
\left.20 \text { and } 30 \mathrm{mg} \mathrm{L} \mathrm{L}^{-1}\right) ; \text { culture } \\
\text { temperature: } 25 \pm 2{ }^{\circ} \mathrm{C}( \pm 1) ; \\
\text { photoperiod: } 24: 0 \text {; light intensity: } \\
\quad 10 \mathrm{Wm}^{-2} \text {; time: } 120 \mathrm{~h} .\end{array}$ & $\mathrm{Cr}$ & Cr: $66.4 \%$ & [177] \\
\hline
\end{tabular}


Table 5. Cont.

\begin{tabular}{|c|c|c|c|c|}
\hline Strain & Operating Conditions & Parameters & Removal Efficiency & Reference \\
\hline S. quadricauda & 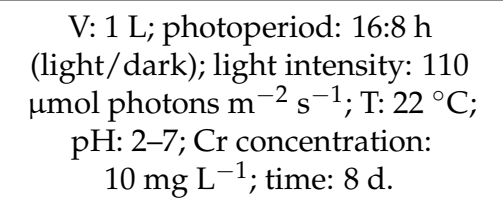 & $\mathrm{Cr}(\mathrm{VI})$ & Cr: $98 \%$ & [12] \\
\hline $\begin{array}{l}\text { Chlorella vulgaris } \\
\text { Pseudochlorella } \\
\text { pringsheimii }\end{array}$ & $\begin{array}{l}\text { V: } 0.3 \mathrm{~L} \text {; tanning effluents dilution: } \\
\text { 10-50\%; photoperiod: } 24: 0 \mathrm{~h} \\
\text { (light/dark); } \mathrm{T}: 27^{\circ} \mathrm{C} ; \\
\text { light intensity: } \\
35 \mu \mathrm{mol} \text { photons } \mathrm{m}^{-2} \mathrm{~s}^{-1}\end{array}$ & $\begin{array}{l}\mathrm{NH}_{3}-\mathrm{N} \\
\mathrm{PO}_{4}-\mathrm{P} \\
\mathrm{COD} \\
\mathrm{Cr}\end{array}$ & $\begin{array}{l}\mathrm{NH}_{3}-\mathrm{N}: 100 \% \\
\mathrm{PO}_{4}-\mathrm{P}: 63 \% \\
\text { COD: } 80 \% \\
\text { Cr: } 56 \%\end{array}$ & [43] \\
\hline $\begin{array}{l}\text { C. pyrenoidosa } \\
\text { Scenedesmus sp. }\end{array}$ & $\begin{array}{l}\text { V: } 0.25 \mathrm{~L} ; \text { photoperiod: } 12: 12 \mathrm{~h} ; \mathrm{T}: \\
27^{\circ} \mathrm{C} \text {; tannery effluent } \\
\text { concentration: } \\
\text { 0-10-25-50-75-100\%; pH: 7; } \\
\text { time: } 12 \mathrm{~d} .\end{array}$ & $\mathrm{Cr}$ & Cr: $75 \%$ & [182] \\
\hline Tetraselmis sp. & $\begin{array}{c}\text { V: } 0.25 \mathrm{~L} ; \mathrm{T}: 24{ }^{\circ} \mathrm{C} \text {; photoperiod: } \\
\text { 24:0 h (light/dark); time } 19 \mathrm{~d} \text {; } \\
\text { tannery effluent concentration: } \\
50-75 \% .\end{array}$ & $\begin{array}{c}\text { Total Kjeldahl Nitrogen } \\
\text { (TNK) } \\
\mathrm{NH}_{3}-\mathrm{N} \\
\mathrm{PO}_{4}-\mathrm{P} \\
\text { Chemical oxygen } \\
\text { demand (COD) }\end{array}$ & $\begin{array}{c}\mathrm{NH}_{3}-\mathrm{N}: 99.90 \% \\
\text { TKN: } 79.36 \% \\
\text { PO }_{4}-\mathrm{P}: 87.82 \% \\
\text { COD: } 14.26 \%\end{array}$ & [16] \\
\hline $\begin{array}{l}\text { C. vulgaris } \\
\text { S. acutus }\end{array}$ & $\begin{array}{c}\text { V: } 10 \mathrm{~L} ; \mathrm{T}: 24 \pm 2{ }^{\circ} \mathrm{C} ; \mathrm{pH}: 6.3 \pm 0.3 \\
\text { time: } 8-10 \text { d.; illumination: } \\
4500 \pm 50 \text { lux; photoperiod: } 16: 8 \mathrm{~h} \\
\text { (light/dark). }\end{array}$ & $\mathrm{Cr}$ & $\begin{array}{c}\text { Cr: } 88.2 \% \text { (C. vulgaris) } \\
\text { 87.1\% (S. acutus) }\end{array}$ & [184] \\
\hline C. vulgaris & $\begin{array}{l}\text { V: } 0.1 \mathrm{~L} \text {; water concentration: } \\
\text { 100-70-50-30-10\%; T: } 28 \pm 0.5^{\circ} \mathrm{C} \text {; } \\
\text { fluorescent lights: } 150-300 \mu \mathrm{mol} \\
\text { photons } \mathrm{m}^{-2} \mathrm{~s}^{-1} ; \text { photoperiod: } \\
\text { 10:14 h (light/dark); time: } 21 \text { days. }\end{array}$ & $\begin{array}{c}\mathrm{BOD} \\
\mathrm{COD} \\
\mathrm{NO}_{3}-\mathrm{N} \\
\mathrm{PO}_{4}-\mathrm{P} \\
\mathrm{SO}_{4}-\mathrm{S} \\
\mathrm{Cr}\end{array}$ & $\begin{array}{c}\mathrm{NO}_{3}-\mathrm{N}: 100 \% \\
\text { Cr: } 91.73 \% \\
\mathrm{PO}_{4}: 99 \% \\
\mathrm{SO}_{4}: 67.4 \% \\
\text { COD: } 94.74 \% \\
\text { BOD: } 95.93 \%\end{array}$ & [42] \\
\hline $\begin{array}{l}\text { Scenedesmus sp. } \\
\text { C. variabilis } \\
\text { C. sorokiniana }\end{array}$ & $\begin{array}{l}\mathrm{V}: 0.1 \mathrm{~L} ; \mathrm{T}: 25^{\circ} \mathrm{C} \text {, illumination: } \\
40 \mu \mathrm{mol} \text { photons } \mathrm{m}^{-2} \mathrm{~s}^{-1} \\
\text { photoperiod: } 14: 10 \mathrm{~h} \text { (light/dark); } \\
\text { concentration: } 25-40-60 \% \text {. }\end{array}$ & $\begin{array}{c}\mathrm{COD} \\
\mathrm{NH}_{4}-\mathrm{N} \\
\mathrm{PO}_{4}^{3-}-\mathrm{P}\end{array}$ & $\begin{array}{c}\text { Scenedesmus sp.: } \\
\text { COD: } 66 \% \text { and } 56 \% \\
\mathrm{NH}_{4}: 47 \% \text { and } 39 \% \\
\mathrm{PO}_{4}{ }^{3-}: 70 \% \text { and } 64 \% \\
\text { C. variabilis: } \\
\text { COD: } 84 \% \text { and } 80 \% \\
\mathrm{NH}_{4}: 68 \% \text { and } 62 \% \\
\mathrm{PO}_{4}{ }^{3-}: 93 \% \text { and } 87 \% \\
\text { C. sorokiniana: } \\
\text { COD: } 80 \% \text { and } 74 \% \\
\mathrm{NH}_{4}: 74 \% \text { and } 56 \% \\
\mathrm{PO}_{4}{ }^{3-}: 93 \% \text { and } 93 \%\end{array}$ & [2] \\
\hline Scenedesmus sp. & $\begin{array}{l}\text { V: } 0.5 \mathrm{~L} \text {; wastewater concentration: } \\
\text { 20-50-100\%; photoperiod: } 16: 8 \mathrm{~h} \\
\text { (light/dark); T: } 24{ }^{\circ} \mathrm{C} \text {; time: } 15 \mathrm{~d} \text {. } \\
\text { The } 100 \% \text { concentration was used } \\
\text { for nutrient removal experiments. }\end{array}$ & $\begin{array}{c}\mathrm{Cr}(\mathrm{VI}) \\
\mathrm{NO}_{2}-\mathrm{N} \\
\mathrm{NO}_{3}-\mathrm{N} \\
\mathrm{PO}_{4}-\mathrm{P} \\
\mathrm{SO}_{4}-\mathrm{S} \\
\mathrm{DBO}\end{array}$ & $\begin{array}{c}\mathrm{Cr}^{+6}: 98 \% \\
\mathrm{NO}_{2}: 95 \% \\
\mathrm{NO}_{3}: 90 \% \\
\mathrm{PO}_{4}: 99 \% \\
\mathrm{SO}_{4}: 92 \% \\
\mathrm{BOD}_{5}: 88 \%\end{array}$ & [170] \\
\hline
\end{tabular}


Table 5. Cont.

\begin{tabular}{|c|c|c|c|c|}
\hline Strain & Operating Conditions & Parameters & Removal Efficiency & Reference \\
\hline $\begin{array}{c}\text { Microalgae consortium. } \\
\text { Dominant microalgae: } \\
\text { Tetraselmis sp. }\end{array}$ & $\begin{array}{l}\text { V: } 0.25 \mathrm{~L} \text {; wastewater } \\
\text { concentration: } 50 \mathrm{R} 50 \mathrm{~S} \text { and } 75 \mathrm{R} 25 \mathrm{~S} \text {; } \\
\text { photoperiod: } 12: 12 \mathrm{~h} \text { (light/dark); } \\
\text { air flow: } 1 \mathrm{~L} \min ^{-1} \text {; time: } 20 \text { days. }\end{array}$ & $\begin{array}{c}\mathrm{PO}_{4}-\mathrm{P} \\
\text { Total nitrogen }(\mathrm{TN}) \\
\mathrm{NH}_{3}-\mathrm{N} \\
\mathrm{COD} \\
\mathrm{TOC} \\
\mathrm{BOD}\end{array}$ & 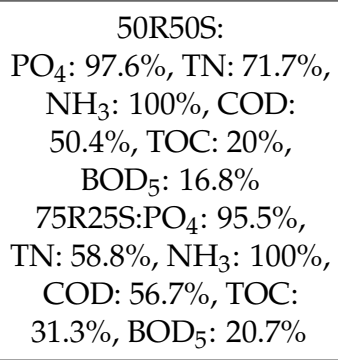 & {$[7]$} \\
\hline Scenedesmus sp. & $\begin{array}{l}\text { V: } 0.15 \mathrm{~L} \text {; tannery wastewater } \\
\text { dilutions: } 10 \%, 25 \%, 50 \%, 75 \% \text { and } \\
\text { 100\%; T: } 27 \pm 2{ }^{\circ} \mathrm{C} \text {; illumination: } \\
\text { 4000 lux; photoperiod: } 16: 8 \mathrm{~h} \\
\text { (dark/light); time: } 12 \mathrm{~d} .\end{array}$ & $\begin{array}{l}\mathrm{Cr} \\
\mathrm{Cu} \\
\mathrm{Pb} \\
\mathrm{Zn} \\
\mathrm{NO}_{3} \\
\mathrm{PO}_{4}\end{array}$ & $\begin{array}{c}\mathrm{Cr}: 81.2-96 \% \\
\mathrm{Cu}: 73.2-98 \% \\
\mathrm{~Pb}: 75-98 \% \\
\mathrm{Zn:} 65-98 \% \\
\mathrm{NO}_{3}>44.3 \% \\
\mathrm{PO}_{4}>95 \%\end{array}$ & {$[30]$} \\
\hline C. vulgaris & $\begin{array}{l}\qquad \mathrm{V} \text { : } 0.25 \mathrm{~L} ; \mathrm{T}: 26 \pm 2{ }^{\circ} \mathrm{C} \text {; } \\
\text { illumination: } 5000 \text { lux; wastewater } \\
\text { concentration: } 100 \% \text {; pH: } 7.1 \text {; time: } \\
15 \mathrm{~d} .\end{array}$ & $\begin{array}{l}\mathrm{NO}_{3}-\mathrm{N} \\
\mathrm{NH}_{4}-\mathrm{N} \\
\mathrm{PO}_{4}-\mathrm{P} \\
\mathrm{COD}\end{array}$ & $\begin{array}{c}\mathrm{NH}_{4}: 55 \% \\
\mathrm{NO}_{3}: 85.6 \% \\
\mathrm{PO}_{4}: 60.5 \% \\
\mathrm{COD}: 43.4 \%\end{array}$ & [186] \\
\hline Chlorella sp. & $\begin{array}{l}\text { V: } 0.3 \text { L; wastewater tannery } \\
\text { concentration: } 50-100 \% \text {; time: } \\
12 \text { d; T: } 27.5^{\circ} \mathrm{C} \text {; illumination: } \\
4000 \text { lux; photoperiod: } 12: 12 \mathrm{~h} \\
\quad \text { (fluorescent lamps). }\end{array}$ & $\begin{array}{l}\mathrm{Cr} \\
\mathrm{Cu} \\
\mathrm{Pb} \\
\mathrm{Zn}\end{array}$ & $\begin{array}{c}\text { 50\% dilution: } \\
\text { Cr: } 73.1 \%, 45.7 \% \\
\text { Cu: } 90.4 \%, 78.1 \% \\
\text { Pb: } 92.1 \%, 52.2 \% \\
\text { Zn: } 81.2 \%, 44.6 \% \\
\text { 100\% wastewater: } \\
\text { Cr: } 45.7 \% \\
\text { Cu: } 78.1 \% \\
\text { Pb: } 52.2 \% \\
\text { Zn: } 44.6 \%\end{array}$ & [186] \\
\hline $\begin{array}{c}\text { Chlorella sp. } \\
\text { Phormidium sp. }\end{array}$ & $\begin{array}{l}\text { V: } 15 \mathrm{~L} \text {; tannery wastewater: } 100 \% \text {; } \\
\text { time: } 20 \mathrm{~d} \text {; } \mathrm{T}: 28{ }^{\circ} \mathrm{C} \text {; light intensity: } \\
225 \mu \text { mol photons } \mathrm{m}^{-2} \mathrm{~s}^{-1} \\
\text { photoperiod: } 12: 12 \mathrm{~h}\end{array}$ & $\begin{array}{c}\text { BOD } \\
\text { COD } \\
\text { TN } \\
\text { Total phosphorus } \\
\text { (TP) } \\
\text { Cr } \\
\text { TDS }\end{array}$ & $\begin{array}{c}\text { BOD: } 93.4 \% \\
\text { COD: } 96.6 \pm 11.1 \% \\
\text { TN: } 91.16 \% \\
\text { TP: } 88 \% \\
\text { Cr: } 94.45 \% \\
\text { TDS: } 58.28 \%\end{array}$ & {$[173]$} \\
\hline
\end{tabular}

\section{Present and Future Prospects}

Currently, the implementation of composite systems between advanced oxidation and phytoremediation processes are being evaluated (Figure 4). Studies have shown an optimal correlation between ozonation and phytoremediation with the microalgae Nannochloropsis oculata, where a removal of $84 \%$ was achieved for COD, $60 \%$ for color, $100 \%$ for odor, $90 \%$ for inorganic carbon, $84 \%$ for $\mathrm{NH}_{4}{ }^{+}-\mathrm{N}, 100 \%$ for $\mathrm{PO}_{4}-\mathrm{P}, 97 \%$ for chromium and $10 \%$ for TDS; however, it is necessary to maximize the efficiency of ozone utilization to minimize operating costs and continue research regarding operating conditions [43]. Microalgae have demonstrated their ability to absorb various heavy metals, exhibiting greater effectiveness under certain conditions, as in the case of Dunaliella salina, which exhibited a greater capacity for chromium (VI) biosorption with an efficiency of $66.4 \%$ at an optimal $\mathrm{pH}$ (8.6) and an inoculum size of $10 \%$ within the first $120 \mathrm{~h}$, demonstrating a viable solution for the bioremediation of wastewater with a high content of heavy metals [177]. 


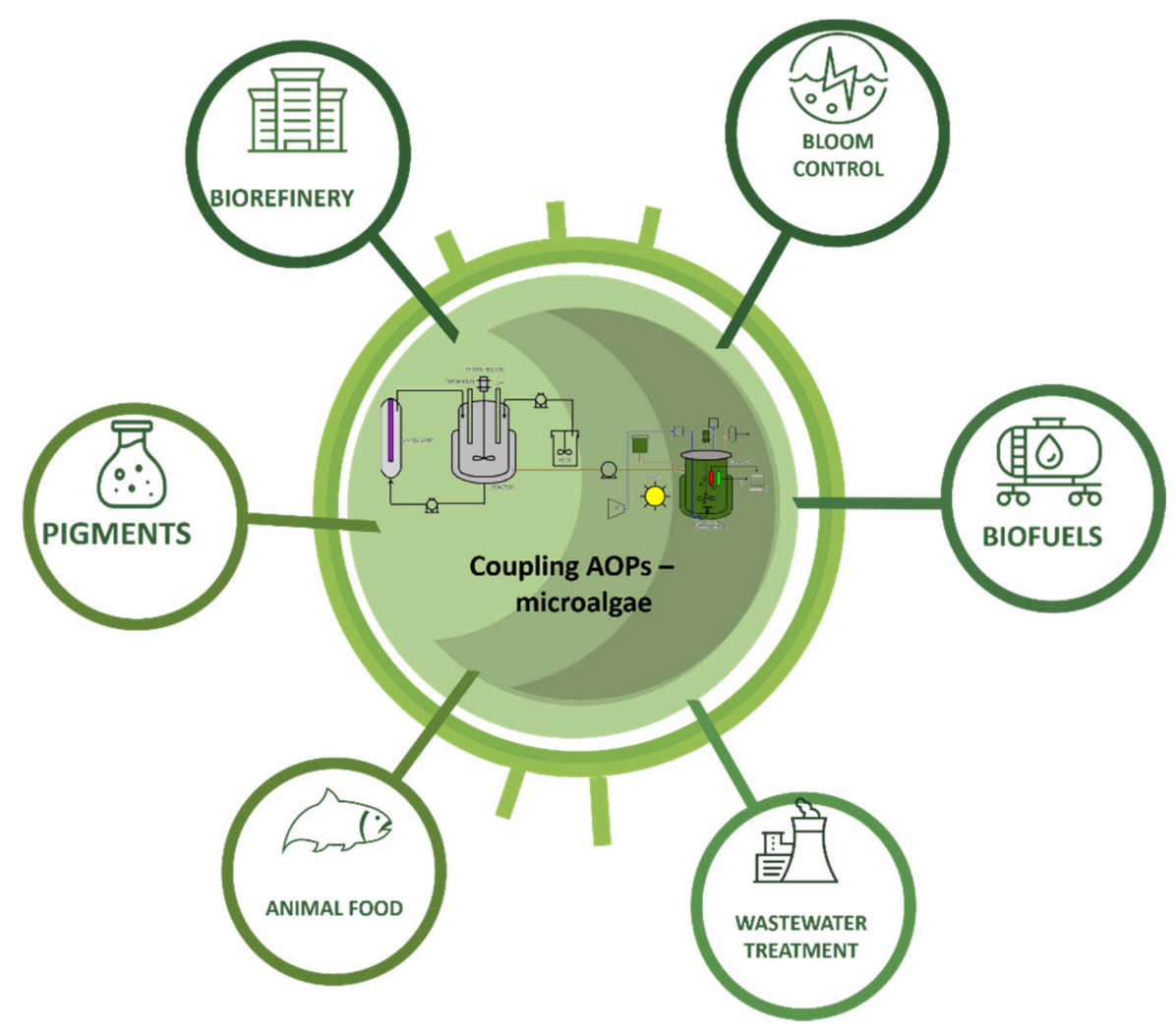

Figure 4. Biotechnological applications of the coupling of microalgae and AOPs.

The above demonstrates the capacity of microalgae to reduce most of the highly environmentally polluting compounds in tannery wastewater, which would allow it to be an ecological strategy through the establishment of bioremediation centers and economic biorefineries to recover resources, guaranteeing the recovery of chromium for reuse in the tanning process and promoting sustainable economic development $[185,187]$. The use of microalgal biomass resulting from the biomeremediation process of tannery effluents to obtain biofuels has been reported due to the accumulation of lipids [188] being the main use; the success of the commercial application of these biofuels is associated with the biorefining of other metabolites such as pigments or renewable polymers that can be used [189]. Finally, the path to commercialization of the microalgae fuel is related to the implementation of improvements in metabolic engineering, synthetic biology and genomics, the development of closed photobioreactor systems and the invention of new lighting, harvesting, and extraction systems [188]. Advanced oxidation processes and biological processes have gained popularity in recent years; however, they require further study to specify the optimal conditions for their operation. Therefore, one of the prospects in the tannery wastewater treatment technology is the development of various investigations that promote the combined use of AOPs and the microalgae biotechnology, where operating conditions are evaluated and variables are determined, that allow improving productivity of the biomass and metabolites of interest with a potential in various sectors of the industry.

\section{Conclusions}

In recent years, different strategies have been implemented for the treatment of tannery wastewater, as this process leads to the generation of polluting loads with high environmental impact. However, the main treatment systems, although efficient, can become expensive, difficult to operate and at the same time generate secondary waste that turns out to be more toxic than the raw wastewater would be. For this reason, over the years, it has been sought to design strategies that allow easy access and are efficient in removing the pollutant load. 
Advanced oxidation processes and biological processes have gained popularity in the recent years; however, they require further study to specify the optimal conditions for their operation. Among the main biological processes for the treatment of tannery waters is phycoremediation with microalgae since their adaptive capacity to stress situations allows them to develop adequately in this type of water. Therefore, various investigations have been developed that promote its use, finding high removal efficiencies and the implementation of combined systems. Despite this, further studies are required to determine the adaptive capacity of various strains since currently the most widely used are Scenedesmus sp. and Chlorella sp. Among the main advantages of the implementation of microalgae in tannery wastewater is the reuse of nitrogen and phosphorus remaining from the tanning process as nutrients for its metabolism, its ability to generate metabolites of industrial interest obtained due to the stress developed during growth in this medium and the bioabsorption capacity of chromium for its subsequent recovery. For these reasons, phytoremediation with microalgae coupled to advanced oxidation processes such as tannery wastewater treatment promises to be a viable strategy, being an affordable, ecosustainable process, with efficient removal and better productivity of the microalgal biomass.

Author Contributions: Conceptualization, F.M.-M.; Data curation, A.F.B.-S. and N.A.U.-S.; Funding acquisition, F.M.-M.; Investigation, N.A.U.-S. and A.F.B.-S.; Resources, F.M.-M.; Software, N.A.U.S. and F.M.-M.; Supervision, A.F.B.-S. and F.M.-M.; Writing—original draft preparation, N.A.U.-S.; Writing - review and editing, A.F.B.-S. and F.M.-M. All authors have read and agreed to the published version of the manuscript.

Funding: This review was supported by Universidad del Valle (Colombia) with the project "Evaluación de un sistema acoplado de oxidación avanzada en efluentes industriales y producción de microalgas para la obtención de metabolitos de alto valor agregado Grant CI 21144" and by the Newton Fund Institutional Links (ID 527624805).

Acknowledgments: We would like to express our sincere gratitude to Universidad del Valle and Universidad Francisco de Paula Santander for providing the equipment for this review and the Colombian Ministry of Science, Technology and Innovation MINCIENCIAS for the support of national PhD doctorates through the Francisco José de Caldas scholarship program.

Conflicts of Interest: The authors declare no conflict of interest.

\begin{tabular}{|c|c|}
\hline \multicolumn{2}{|c|}{ Abbreviations } \\
\hline AOPs & advanced oxidation processes \\
\hline BOD & biological oxygen demand \\
\hline $\mathrm{Cr}$ & chromium \\
\hline COD & chemical oxygen demand \\
\hline EC & electrochemical \\
\hline $\mathrm{EF}$ & electro-Fenton \\
\hline EEO & electrical energy per order \\
\hline EEM & electrical energy per mass \\
\hline $\mathrm{H}_{2} \mathrm{O}_{2}$ & peroxide hydrogen \\
\hline LP-UV & low-pressure ultraviolet lamp \\
\hline MFC & microbial fuel cell \\
\hline MP-UV & medium-pressure ultraviolet lamp \\
\hline MLVSS & suspended solids of mixed liquor \\
\hline $\mathrm{O}_{3}$ & ozone \\
\hline TDS & total dissolved solids \\
\hline TKN & total Kjeldahl nitrogen \\
\hline TOC & total organic carbon \\
\hline TSS & total suspended solids \\
\hline US & ultrasound \\
\hline UV & ultraviolet \\
\hline
\end{tabular}




\section{References}

1. Gallego-Molina, A.; Mendoza-Roca, J.A.; Aguado, D.; Galiana-Aleixandre, M.V. Reducing Pollution from the Deliming-Bating Operation in a Tannery. Wastewater Reuse by Microfiltration Membranes. Chem. Eng. Res. Des. 2013, 91, 369-376. [CrossRef]

2. Nagi, M.; He, M.; Li, D.; Gebreluel, T.; Cheng, B.; Wang, C. Utilization of Tannery Wastewater for Biofuel Production: New Insights on Microalgae Growth and Biomass Production. Sci. Rep. 2020, 10, 1530. [CrossRef] [PubMed]

3. FAOSTAT. Crops and Livestock Products. Available online: http://www.fao.org/faostat/en/\#data/TP (accessed on 22 March 2021).

4. The Confederation of National Associations of Tanners and Dressers of the European Community (COTANCE). Available online: https:/ / euroleather.com (accessed on 22 March 2021).

5. Martinez, B.S.Y.; Romero, C.J.A. Revisión Del Estado Actual De La Industria De Las Curtiembres En Sus Procesos Y Productos: Un análisis De Su Competitividad. Rev. Fac. Cien. Econ. 2017, 26, 113-124.

6. Lofrano, G.; Belgiorno, V.; Gallo, M.; Raimo, A.; Meriç, S. Toxicity reduction in leather tanning wastewater by improved coagulation flocculation process. Glob. NEST J. 2006, 8, 151-158. [CrossRef]

7. Pena, A.C.; Trierweiler, L.F.; Gutterres, M. Influence of photoperiod on biomass production and removal of nutrients from tannery effluents with microalgae consortium. In Proceedings of the XXXV IULTCS Congress 2019; Tegtmeyer, D., Meyer, M., Eds.; Association for Tannery Chemistry and Technology: Dresden, Germany, 2019; Volume 4, p. 19.

8. Ouaissa, Y.A.; Chabani, M.; Amrane, A.; Bensmaili, A. Integration of Electro Coagulation and Adsorption for the Treatment of Tannery Wastewater-The Case of an Algerian Factory, Rouiba. Procedia Eng. 2012, 33, 98-101. [CrossRef]

9. Hansen, É.; Monteiro de Aquim, P.; Hansen, A.W.; Cardoso, J.K.; Ziulkoski, A.L.; Gutterres, M. Impact of Post-Tanning Chemicals on the Pollution Load of Tannery Wastewater. J. Environ. Manag. 2020, 269, 110787. [CrossRef]

10. Aravindhan, R.; Madhan, B.; Rao, J.R.; Nair, B.U.; Ramasami, T. Bioaccumulation of Chromium from Tannery Wastewater: An Approach for Chrome Recovery and Reuse. Environ. Sci. Technol. 2004, 38, 300-306. [CrossRef]

11. Chhikara, S.; Hooda, A.; Rana, L.; Dhankhar, R. Chromium (VI) Biosorption by Immobilized Aspergillus niger in Continuous Flow System with Special Reference to FTIR Analysis. J. Environ. Biol. 2010, 31, 561-566. Available online: http://jeb.co.in/journal_ issues/201009_sep10/paper_03.pdf (accessed on 22 March 2020). [PubMed]

12. Daneshvar, E.; Zarrinmehr, M.J.; Kousha, M.; Hashtjin, A.M.; Saratale, G.D.; Maiti, A.; Vithanage, M.; Bhatnagar, A. Hexavalent Chromium Removal from Water by Microalgal-Based Materials: Adsorption, Desorption and Recovery Studies. Bioresour. Technol. 2019, 293, 122064. [CrossRef]

13. da Fontoura, J.T.; Rolim, G.S.; Farenzena, M.; Gutterres, M. Influence of Light Intensity and Tannery Wastewater Concentration on Biomass Production and Nutrient Removal by Microalgae Scenedesmus sp. Process Safe Environ. Prot. 2017, 111, 355-362. [CrossRef]

14. Mohd Udaiyappan, A.F.; Abu Hasan, H.; Takriff, M.S.; Sheikh Abdullah, S.R. A Review of the Potentials, Challenges and Current Status of Microalgae Biomass Applications in Industrial Wastewater Treatment. J. Water Process Eng. 2017, 20, 8-21. [CrossRef]

15. Crini, G.; Lichtfouse, E. Advantages and Disadvantages of Techniques Used for Wastewater Treatment. Environ. Chem. Lett. 2019, 17, 145-155. [CrossRef]

16. Pena, A.d.C.C.; Bertoldi, C.F.; da Fontoura, J.T.; Trierweiler, L.F.; Gutterres, M. Consortium of Microalgae for Tannery Effluent Treatment. Braz. Arch. Biol. Technol. 2019, 62. [CrossRef]

17. Quintero-Dallos, V.; García-Martínez, J.B.; Contreras-Ropero, J.E.; Barajas-Solano, A.F.; Barajas-Ferrerira, C.; Lavecchia, R.; Zuorro, A. Vinasse as a Sustainable Medium for the Production of Chlorella vulgaris UTEX 1803. Water 2019, 11, 1526. [CrossRef]

18. Guiza-Franco, L.; Orozco-Rojas, L.G.; Sánchez-Galvis, E.M.; García-Martínez, J.B.; Barajas-Ferreira, C.; Zuorro, A.; Barajas-Solano, A.F. Production of Chlorella vulgaris Biomass on Uv-Treated Wastewater as an Alternative for Environmental Sustainability on High-Mountain Fisheries. Chem. Eng. Trans. 2018, 64, 517-522. [CrossRef]

19. Garcia-Martinez, J.B.; Urbina-Suarez, N.A.; Zuorro, A.; Barajas-Solano, A.F.; Kafarov, V. Fisheries Wastewater as a Sustainable Media for the Production of Algae-Based Products. Chem. Eng. Trans. 2019, 76, 1339-1344. [CrossRef]

20. Estévez-Landazábal, L.L.; Barajas-Solano, A.F.; Barajas-Ferreira, C.; Kafarov, V. Improvement of lipid productivity on Chlorella vulgaris using waste glycerol and sodium acetate. CTF Cienc. Tecnol. Futuro 2013, 5, 113-126. Available online: http:/ / www.scielo. org.co/scielo.php?script=sci_arttext\&pid=S0122-53832013000100009 (accessed on 22 March 2021).

21. Yen, H.-W.; Chen, P.-W.; Hsu, C.-Y.; Lee, L. The Use of Autotrophic Chlorella vulgaris in Chromium (VI) Reduction under Different Reduction Conditions. J. Taiwan Inst. Chem. Eng. 2017, 74, 1-6. [CrossRef]

22. Garcia-Martinez, B.; Ayala-Torres, E.; Reyes-Gomez, O.; Zuorro, A.; Barajas-Solano, A.; Barajas-Ferreira, C. Evaluation of a Two-Phase Extraction System of Carbohydrates and Proteins from Chlorella vulgaris Utex 1803. Chem. Eng. Trans. 2016, 49, 355-360. [CrossRef]

23. Barajas-Solano, A.F.; Guzmán-Monsalve, A.; Kafarov, V. Effect of Carbon-Nitrogen Ratio for the Biomass Production, Hydrocarbons and Lipids on Botryoccus braunii UIS 003. Chem. Eng. Trans. 2016, 49, 247-252. [CrossRef]

24. Cuéllar-García, D.J.; Rangel-Basto, Y.A.; Urbina-Suarez, N.A.; Barajas-Solano, A.F.; Muñoz-Peñaloza, Y.A. Lipids production from Scenedesmus obliquus through carbon/nitrogen ratio optimization. J. Phys. Conf. Ser. 2019, 1388, 012043. [CrossRef]

25. Cuéllar-García, D.J.; Rangel-Basto, Y.A.; Barajas-Solano, A.F.; Muñoz-Peñaloza, Y.A.; Urbina-Suarez, N.A. Towards the production of microalgae biofuels: The effect of the culture medium on lipid deposition. BioTechnologia 2019, 100, 273-278. [CrossRef] 
26. Zuorro, A.; Leal-Jerez, A.G.; Morales-Rivas, L.K.; Mogollón-Londoño, S.O.; Sanchez-Galvis, E.M.; García-Martínez, J.B.; BarajasSolano, A.F. Enhancement of Phycobiliprotein Accumulation in Thermotolerant Oscillatoria sp. through Media Optimization. ACS Omega 2021, 6, 10527-10536. [CrossRef]

27. Rangel-Basto, Y.A.; García-Ochoa, I.E.; Suarez-Gelvez, J.H.; Zuorro, A.; Barajas-Solano, A.F.; Urbina-Suarez, N.A. The Effect of Temperature and Enzyme Concentration in the Transesterification Process of Synthetic Microalgae Oil. Chem. Eng. Trans. 2018, 64, 331-336. [CrossRef]

28. Barajas-Solano, A.F.; Gonzalez-Delgado, A.D.; Kafarov, V. Effect of Thermal Pre-Treatment on Fermentable Sugar Production of Chlorella vulgaris. Chem. Eng. Trans. 2014, 37, 655-660. [CrossRef]

29. Zuorro, A.; García-Martínez, J.B.; Barajas-Solano, A.F. The Application of Catalytic Processes on the Production of Algae-Based Biofuels: A Review. Catalysts 2021, 11, 22. [CrossRef]

30. Ajayan, K.V.; Selvaraju, M.; Unnikannan, P.; Sruthi, P. Phycoremediation of Tannery Wastewater Using Microalgae Scenedesmus Species. Int. J. Phytoremed. 2015, 17, 907-916. [CrossRef]

31. Suárez Escobar, A.F.; García Ubaque, C.A.; Vaca Bohórquez, M.L. Identificación y evaluación de la contaminación del agua por curtiembres en el municipio de Villapinzón. Tecnura 2012, 16, 185-193. [CrossRef]

32. Carreño, S.U.F. Diseño y evaluación de un biosistema de tratamiento a escala piloto de aguas de curtiembres a través de la Eichhornia crassipes. Rev. Colomb. Biotecnol. 2016, 18, 74-81. [CrossRef]

33. Quintero Salamanca, G.P.; Quijano Parra, A.; Melendez Gelvez, I. Efecto genotoxico del agua residual de la curtiembre San Faustino-Norte de Santander-Colombia. Rev. Colomb. Tecnol. Av. 2018, 2, 8-16. [CrossRef]

34. Schilling, K.; Bletterie, U.; Kroiss, H.; Zessner, M. Adapting the Austrian Edict on Wastewater Emissions for Tanneries as Consequence of Foam Formation on Surface Waters. Environ. Sci. Policy 2012, 23, 68-73. [CrossRef]

35. Genawi, N.M.; Ibrahim, M.H.; El-Naas, M.H.; Alshaik, A.E. Chromium Removal from Tannery Wastewater by Electrocoagulation: Optimization and Sludge Characterization. Water 2020, 12, 1374. [CrossRef]

36. Tolkou, A.K.; Zouboulis, A.I. Application of Composite Pre-Polymerized Coagulants for the Treatment of High-Strength Industrial Wastewaters. Water 2020, 12, 1258. [CrossRef]

37. Bharagava, R.N.; Mishra, S. Hexavalent Chromium Reduction Potential of Cellulosimicrobium sp. Isolated from Common Effluent Treatment Plant of Tannery Industries. Ecotoxicol. Environ. Saf. 2018, 147, 102-109. [CrossRef]

38. Palanisamy, D.; Chockalingam, L.R.; Murugan, D. Microbial Fuel Cell for Effluent Treatment and Sustainable Power Generation. Energy Sources Part A Recover. Util. Environ. Eff. 2020, 1-13. [CrossRef]

39. Tamil Selvan, S.; Velramar, B.; Ramamurthy, D.; Balasundaram, S.; Sivamani, K. Pilot Scale Wastewater Treatment, $\mathrm{CO}_{2}$ Sequestration and Lipid Production Using Microalga, Neochloris aquatica RDS02. Int. J. Phytoremed. 2020, 22, 1462-1479. [CrossRef] [PubMed]

40. Mustapha, S.; Ndamitso, M.M.; Abdulkareem, A.S.; Tijani, J.O.; Mohammed, A.K.; Shuaib, D.T. Potential of Using Kaolin as a Natural Adsorbent for the Removal of Pollutants from Tannery Wastewater. Heliyon 2019, 5, e02923. [CrossRef]

41. Yadav, A.; Raj, A.; Purchase, D.; Ferreira, L.F.R.; Saratale, G.D.; Bharagava, R.N. Phytotoxicity, Cytotoxicity and Genotoxicity Evaluation of Organic and Inorganic Pollutants Rich Tannery Wastewater from a Common Effluent Treatment Plant (CETP) in Unnao District, India Using Vigna radiata and Allium cepa. Chemosphere 2019, 224, 324-332. [CrossRef]

42. Das, C.; Naseera, K.; Ram, A.; Meena, R.M.; Ramaiah, N. Bioremediation of Tannery Wastewater by a Salt-Tolerant Strain of Chlorella Vulgaris. J. Appl. Phycol. 2017, 29, 235-243. [CrossRef]

43. Saranya, D.; Shanthakumar, S. An Integrated Approach for Tannery Effluent Treatment with Ozonation and Phycoremediation: A Feasibility Study. Environ. Res. 2020, 183, 109163. [CrossRef] [PubMed]

44. Reyes-Serrano, A.; López-Alejo, J.E.; Hernández-Cortázar, M.A.; Elizalde, I. Removing Contaminants from Tannery Wastewater by Chemical Precipitation Using $\mathrm{CaO}$ and $\mathrm{Ca}(\mathrm{OH})_{2}$. Chin. J. Chem. Eng. 2020, 28, 1107-1111. [CrossRef]

45. Khanh, T.K.; Jyh, L.H.; Quyet, V.T.; Tam, M.M.; Anh, P.T.; Kiefer, R. Hydrogen Production from the Tannery Wastewater Treatment by Using Agriculture Supports Membrane/Adsorbents Electrochemical System. Int. J. Hydrogen Energy 2020, 45, 3699-3711. [CrossRef]

46. Boujelben, R.; Ellouze, M.; Sayadi, S. Detoxification Assays of Tunisian Tannery Wastewater under Nonsterile Conditions Using the Filamentous Fungus Aspergillus niger. BioMed Res. Int. 2019, 2019, 9020178. [CrossRef]

47. Goswami, S.; Mazumder, D. Treatment of Chrome Tannery Wastewater by Biological Process-A Mini Review. Int. J. Environ. Ecol. Eng. 2013, 7, 798-804.

48. El Mouhri, G.; Merzouki, M.; Belhassan, H.; Miyah, Y.; Amakdouf, H.; Elmountassir, R.; Lahrichi, A. Continuous Adsorption Modeling and Fixed Bed Column Studies: Adsorption of Tannery Wastewater Pollutants Using Beach Sand. J. Chem. 2020, 2020, 7613484. [CrossRef]

49. Aguilar-Ascón, E.; Marrufo-Saldaña, L.; Neyra-Ascón, W. Reduction of Total Chromium Levels from Raw Tannery Wastewater via Electrocoagulation Using Response Surface Methodology. J. Ecol. Eng. 2019, 20, 217-224. [CrossRef]

50. Korpe, S.; Bethi, B.; Sonawane, S.H.; Jayakumar, K.V. Tannery Wastewater Treatment by Cavitation Combined with Advanced Oxidation Process (AOP). Ultrason. Sonochem. 2019, 59, 104723. [CrossRef] [PubMed]

51. Alemu, T.; Mekonnen, A.; Leta, S. Integrated Tannery Wastewater Treatment for Effluent Reuse for Irrigation: Encouraging Water Efficiency and Sustainable Development in Developing Countries. J. Water Process Eng. 2019, 30, 100514. [CrossRef] 
52. Caliari, P.C.; Pacheco, M.J.; Ciríaco, L.; Lopes, A. Tannery Wastewater: Organic Load and Sulfide Removal Dynamics by Electrochemical Oxidation at Different Anode Materials. Environ. Technol. Innov. 2019, 14, 100345. [CrossRef]

53. Hashem, M.A.; Momen, M.A.; Hasan, M.; Nur-A-Tomal, M.S.; Sheikh, M.H.R. Chromium Removal from Tannery Wastewater Using Syzygium Cumini Bark Adsorbent. Int. J. Environ. Sci. Technol. 2019, 16, 1395-1404. [CrossRef]

54. Ashraf, S.; Naveed, M.; Afzal, M.; Ashraf, S.; Rehman, K.; Hussain, A.; Zahir, Z.A. Bioremediation of Tannery Effluent by Cr- and Salt-Tolerant Bacterial Strains. Environ. Monit. Assess. 2018, 190, 716. [CrossRef]

55. Kozik, V.; Barbusinski, K.; Thomas, M.; Sroda, A.; Jampilek, J.; Sochanik, A.; Smolinski, A.; Bak, A. Taguchi Method and Response Surface Methodology in the Treatment of Highly Contaminated Tannery Wastewater Using Commercial Potassium Ferrate. Materials 2019, 12, 3784. [CrossRef]

56. Meenachi, S.; Kandasamy, S. Pre-Treatment of Tannery Chrome Wastewater by Green Synthesised Iron Oxide Nanocatalyst. Int. J. Environ. Anal. Chem. 2019, 1-13. [CrossRef]

57. Ullah, R.; Ahmad, W.; Ahmad, I.; Khan, M.; Iqbal Khattak, M.; Hussain, F. Adsorption and Recovery of Hexavalent Chromium from Tannery Wastewater over Magnetic Max Phase Composite. Sep. Sci. Technol. 2021, 56, 439-452. [CrossRef]

58. Le, L.T. Tannery Wastewater Treatment after Activated Sludge Pre-Treatment Using Electro-Oxidation on Inactive Anodes. Clean Technol. Environ. Policy 2020, 22, 1701-1713. [CrossRef]

59. Pal, M.; Malhotra, M.; Mandal, M.K.; Paine, T.K.; Pal, P. Recycling of Wastewater from Tannery Industry through MembraneIntegrated Hybrid Treatment Using a Novel Graphene Oxide Nanocomposite. J. Water Process Eng. 2020, 36, 101324. [CrossRef]

60. Zhou, L.; Zhang, W.; De Costa, Y.G.; Zhuang, W.-Q.; Yi, S. Assessing Inorganic Components of Cake Layer in A/O Membrane Bioreactor for Physical-Chemical Treated Tannery Effluent. Chemosphere 2020, 250, 126220. [CrossRef] [PubMed]

61. Zapana, J.S.P.; Arán, D.S.; Bocardo, E.F.; Harguinteguy, C.A. Treatment of Tannery Wastewater in a Pilot Scale Hybrid Constructed Wetland System in Arequipa, Peru. Int. J. Environ. Sci. Technol. 2020, 17, 4419-4430. [CrossRef]

62. Arukula, D.; Prem, P.; Tanwi, P.; Hariraj, S.; Vijay, L.M.; Brijesh, K.M. Treatment of tannery wastewater using aluminium formate: Influence of the formate over sulphate-based coagulant. Glob. NEST J. 2018, 20, 458-464. [CrossRef]

63. Chatterjee, S.; Shekhawat, K.; Gupta, N. Bioreduction of Toxic Hexavalent Chromium by Novel Indigenous Microbe Brevibacillus agri Isolated from Tannery Wastewater. Int. J. Environ. Sci. Technol. 2019, 16, 3549-3556. [CrossRef]

64. Chaudhary, P.; Beniwal, V.; Kaur, R.; Kumar, R.; Kumar, A.; Chhokar, V. Efficacy of Aspergillus Fumigatus MCC 1175 for Bioremediation of Tannery Wastewater. Clean Soil Air Water 2019, 47, 1900131. [CrossRef]

65. Belay, A. Impacts of Chromium from Tannery Effluent and Evaluation of Alternative Treatment Options. J. Environ Prot. 2010, 1, 53-58. [CrossRef]

66. Cotman, M.; Zagorc-Končan, J.; Žgajnar-Gotvajn, A. The Relationship between Composition and Toxicity of Tannery Wastewater. Water Sci. Technol. 2004, 49, 39-46. [CrossRef]

67. Ashley, B.B.; Puspha, L.E.; Annadurai, G. Physicochemical Characteristics, Isolation and Screening Of Bacteria For Degradation Of Dyes From Tannery Effluents. Res. J. Life Sci. Bioinf. Pharm. Chem. Sci. 2019, 5, 144-158. [CrossRef]

68. Gutterres, M.; Mella, B. Chromium in Tannery Wastewater. In Heavy Metals in Water: Presence, Removal and Safety; The Royal Society of Chemistry: London, UK, 2015; pp. 315-344. [CrossRef]

69. Prabhahar, C.; Saleshrani, K.; Tharmaraj, K. Seasonal Variation of Heavy Metals Distribution and Sediments in Palar River in and Around Vaniyambadi Segment, Vellore District, Tamil Nadu, India. Int. J. Pharm. Biol. Sci. Arch. 2012, 3, 112-116. Available online: https:/ / www.ijpba.info/ijpba/index.php/ijpba/article/view/546 (accessed on 22 March 2021).

70. Sawalha, H.; Alsharabaty, R.; Sarsour, S.; Al-Jabari, M. Wastewater from Leather Tanning and Processing in Palestine: Characterization and Management Aspects. J. Environ. Manag. 2019, 251, 109596. [CrossRef] [PubMed]

71. Tamersit, S.; Bouhidel, K.-E.; Zidani, Z. Investigation of Electrodialysis Anti-Fouling Configuration for Desalting and Treating Tannery Unhairing Wastewater: Feasibility of by-Products Recovery and Water Recycling. J. Environ. Manag. 2018, 207, 334-340. [CrossRef] [PubMed]

72. Quijano Parra, A.; Castillo, T.C.; Meléndez Gélvez, I. Potencial mutagénico y genotóxico de aguas residuales de la curtiembre tasajero en la ciudad de Cúcuta, Norte de Santander, Colombia. Rev. U.D.C.A Actual. Divulg. Científica 2015, 18, 13-20. Available online: http:/ / www.scielo.org.co/scielo.php?pid=S0123-42262015000100003\&script=sci_abstract\&tlng=es (accessed on 22 March 2021). [CrossRef]

73. Meriç, S.; De Nicola, E.; Iaccarino, M.; Gallo, M.; Di Gennaro, A.; Morrone, G.; Warnau, M.; Belgiorno, V.; Pagano, G. Toxicity of Leather Tanning Wastewater Effluents in Sea Urchin Early Development and in Marine Microalgae. Chemosphere 2005, 61, 208-217. [CrossRef]

74. Lv, W.; Zhao, K.; Ma, S.; Kong, L.; Dang, Z.; Chen, J.; Zhang, Y.; Hu, J. Process of Removing Heavy Metal Ions and Solids Suspended in Micro-Scale Intensified by Hydrocyclone. J. Clean. Prod. 2020, 263, 121533. [CrossRef]

75. Diaz-Angulo, J.; Porras, J.; Mueses, M.; Torres-Palma, R.A.; Hernandez-Ramirez, A.; Machuca-Martinez, F. Coupling of heterogeneous photocatalysis and photosensitized oxidation for diclofenac degradation: Role of the oxidant species. J. Photochem. Photobiol. A Chem. 2019, 383, 112015. [CrossRef]

76. Song, Z.; Williams, C.J.; Edyvean, R.G.J. Treatment of Tannery Wastewater by Chemical Coagulation. Desalination 2004, 164, 249-259. [CrossRef]

77. Achouri, O.; Panico, A.; Bencheikh-Lehocine, M.; Derbal, K.; Pirozzi, F. Effect of Chemical Coagulation Pretreatment on Anaerobic Digestion of Tannery Wastewater. J. Environ. Eng. 2017, 143, 4017039. [CrossRef] 
78. Donneys-Victoria, D.; Bermúdez-Rubio, D.; Torralba-Ramírez, B.; Marriaga-Cabrales, N.; Machuca-Martínez, F. Removal of indigo carmine dye by electrocoagulation using magnesium anodes with polarity change. Environ. Sci. Pollut. Res. 2019, 26, 7164-7176. [CrossRef] [PubMed]

79. Lara-Ramos, J.A.; Saez, C.; Machuca-Martínez, F.; Rodrigo, M.A. Electro-ozonizers: A new approach for an old problem. Sep. Purif. Technol. 2020, 241. [CrossRef]

80. Mayta, R.; Mayta, J. Remoción de Cromo y Demanda Química de Oxígeno de Aguas Residuales de Curtiembre Por Electrocoagulación. Rev. Soc. Química Perú 2017, 83, 331-340. Available online: http://www.scielo.org.pe/scielo.php?script=sci_arttext\&pid= S1810-634X2017000300008 (accessed on 22 March 2021). [CrossRef]

81. Sanchez-Galvis, E.M.; Cardenas-Gutierrez, I.Y.; Contreras-Ropero, J.E.; García-Martínez, J.B.; Barajas-Solano, A.F.; Zuorro, A. An Innovative Low-Cost Equipment for Electro-Concentration of Microalgal Biomass. Appl. Sci. 2020, 10, 4841. [CrossRef]

82. Castellanos-Estupiñan, M.A.; Sánchez-Galvis, E.M.; García-Martínez, J.B.; Barajas-Ferreira, C.; Zuorro, A.; Barajas-Solano, A.F. Design of an Electroflotation System for the Concentration and Harvesting of Freshwater Microalgae. Chem. Eng. Trans. 2018, 64, 1-6. [CrossRef]

83. Şengil, İ.A.; Kulaç, S.; Özacar, M. Treatment of Tannery Liming Drum Wastewater by Electrocoagulation. J. Hazard. Mater. 2009, 167, 940-946. [CrossRef]

84. Deghles, A.; Kurt, U. Treatment of Tannery Wastewater by a Hybrid Electrocoagulation/Electrodialysis Process. Chem. Eng. Process. Process Intensif. 2016, 104, 43-50. [CrossRef]

85. Szpyrkowicz, L.; Kaul, S.N.; Neti, R.N. Tannery Wastewater Treatment by Electro-Oxidation Coupled with a Biological Process. J. Appl. Electrochem. 2005, 35, 381-390. [CrossRef]

86. Mandal, T.; Dasgupta, D.; Mandal, S.; Datta, S. Treatment of Leather Industry Wastewater by Aerobic Biological and Fenton Oxidation Process. J. Hazard. Mater. 2010, 180, 204-211. [CrossRef]

87. Martín-Domínguez, A.; Rivera-Huerta, M.L.; Pérez-Castrejón, S.; Garrido-Hoyos, S.E.; Villegas-Mendoza, I.E.; Gelover-Santiago, S.L.; Drogui, P.; Buelna, G. Chromium removal from drinking water by redox-assisted coagulation: Chemical versus electrocoagulation. Sep. Purif. Technol. 2018, 200, 266-272. [CrossRef]

88. da Silva, G.S.; dos Santos, F.A.; Roth, G.; Frankenberg, C.L.C. Electroplating for chromium removal from tannery wastewater. Int. J. Environ. Sci. Technol. 2020, 17, 607-614. [CrossRef]

89. Protsenko, V.; Danilov, F. Kinetics and mechanism of chromium electrodeposition from formate and oxalate solutions of Cr(III) compounds. Electrochim. Acta 2009, 54, 5666-5672. [CrossRef]

90. Korshunov, V.N.; Safonov, V.A.; Vykhodtseva, L.N. Structural features of the electrode/solution interface at the reduction of Cr3+(aq) cations on liquid mercury and solid indium electrodes in acidic media. Russ. J. Electrochem. 2008, 44, 255-264. [CrossRef]

91. Ameta, R.K.; Chohadia, A.; Jain, A.; Punjabi, P.B. Fenton and Photo-Fenton Processes. In Advanced Oxidation Processes for Waste Water Treatment, 1st ed.; Ameta, S.C., Ed.; Academic Press: London, UK, 2018; pp. 49-87. [CrossRef]

92. Natarajan, T.S.; Natarajan, K.; Bajaj, H.C.; Tayade, R.J. Study on Identification of Leather Industry Wastewater Constituents and Its Photocatalytic Treatment. Int. J. Environ. Sci. Technol. 2013, 10, 855-864. [CrossRef]

93. Betancourt-Buitrago, L.A.; Hernandez-Ramirez, A.; Colina-Marquez, J.A.; Bustillo-Lecompte, C.F.; Rehmann, L.; MachucaMartinez, F. Recent developments in the photocatalytic treatment of cyanide wastewater: An approach to remediation and recovery of metals. Processes 2019, 7, 225. [CrossRef]

94. Acosta-Herazo, R.; Cañaveral-Velásquez, B.; Pérez-Giraldo, K.; Mueses, M.A.; Pinzón-Cárdenas, M.H.; Machuca-Martínez, F. A MATLAB-based application for modeling and simulation of solar Slurry photocatalytic reactors for environmental applications. Water 2020, 12, 2196. [CrossRef]

95. Vilardi, G.; Ochando-Pulido, J.M.; Stoller, M.; Verdone, N.; Di Palma, L. Fenton Oxidation and Chromium Recovery from Tannery Wastewater by Means of Iron-Based Coated Biomass as Heterogeneous Catalyst in Fixed-Bed Columns. Chem. Eng. J. 2018, 351, 1-11. [CrossRef]

96. Lofrano, G.; Meric, S.; Inglese, M.; Nikolau, A.; Belgiorno, V. Fenton Oxidation Treatment of Tannery Wastewater and Tanning Agents: Synthetic Tannin and Nonylphenol Ethoxylate Based Degreasing Agent. Desalin. Water Treat. 2010, 23, 173-180. [CrossRef]

97. Jessieleena, A.A.; Priyanka, M.; Saravanakumar, M.P. Comparative Study of Fenton, $\mathrm{Fe}^{2+} / \mathrm{NaOCl}$ and $\mathrm{Fe}^{2+} /\left(\mathrm{NH}_{4}\right)_{2} \mathrm{~S}_{2} \mathrm{O}_{8}$ on Tannery Sludge Dewaterability, Degradability of Organics and Leachability of Chromium. J. Hazard. Mater. 2021, 402, 123495. [CrossRef]

98. Borba, F.H.; Pellenz, L.; Bueno, F.; Inticher, J.J.; Braun, L.; Espinoza-Quiñones, F.R.; Trigueros, D.E.G.; de Pauli, A.R.; Módenes, A.N. Pollutant Removal and Biodegradation Assessment of Tannery Effluent Treated by Conventional Fenton Oxidation Process. J. Environ. Chem. Eng. 2018, 6, 7070-7079. [CrossRef]

99. Twort, A.C.; Ratnayaka, D.D.; Brandt, M.J. (Eds.) Specialised and Advanced Water Treatment Processes. In Water Supply, 5th ed.; Butterworth-Heinemann: London, UK, 2000; pp. 406-408. [CrossRef]

100. Módenes, A.N.; Espinoza-Quiñones, F.R.; Borba, F.H.; Manenti, D.R. Performance Evaluation of an Integrated Photo-FentonElectrocoagulation Process Applied to Pollutant Removal from Tannery Effluent in Batch System. Chem. Eng. J. 2012, 197, 1-9. [CrossRef]

101. Ikehata, K.; Li, Y. Ozone-Based Processes. In Advanced Oxidation Processes for Waste Water Treatment, 1st ed.; Ameta, S.C., Ed.; Academic Press: London, UK, 2018; pp. 115-143. [CrossRef] 
102. Di Iaconi, C. Biological Treatment and Ozone Oxidation: Integration or Coupling. Bioresour. Technol. 2012, 106, 63-68. [CrossRef] [PubMed]

103. Radha, K.V.; Sirisha, K. Electrochemical Oxidation Processes. In Advanced Oxidation Processes for Waste Water Treatment, 1st ed.; Ameta, S.C., Ed.; Academic Press: London, UK, 2018; pp. 359-373. [CrossRef]

104. Houshyar, Z.; Khoshfetrat, A.B.; Fatehifar, E. Influence of Ozonation Process on Characteristics of Pre-Alkalized Tannery Effluents. Chem. Eng. J. 2012, 191, 59-65. [CrossRef]

105. Sivagami, K.; Sakthivel, K.P.; Nambi, I.M. Advanced Oxidation Processes for the Treatment of Tannery Wastewater. J. Environ. Chem. Eng. 2018, 6, 3656-3663. [CrossRef]

106. Di Iaconi, C.; Del Moro, G.; De Sanctis, M.; Rossetti, S. A Chemically Enhanced Biological Process for Lowering Operative Costs and Solid Residues of Industrial Recalcitrant Wastewater Treatment. Water Res. 2010, 44, 3635-3644. [CrossRef]

107. Sundarapandiyan, S.; Chandrasekar, R.; Ramanaiah, B.; Krishnan, S.; Saravanan, P. Electrochemical Oxidation and Reuse of Tannery Saline Wastewater. J. Hazard. Mater. 2010, 180, 197-203. [CrossRef]

108. Cruz-Rizo, A.; Gutiérrez-Granados, S.; Salazar, R.; Peralta-Hernández, J.M. Application of Electro-Fenton/BDD Process for Treating Tannery Wastewaters with Industrial Dyes. Sep. Purif. Technol. 2017, 172, 296-302. [CrossRef]

109. Medrano-Rodríguez, F.; Picos-Benítez, A.; Brillas, E.; Bandala, E.R.; Pérez, T.; Peralta-Hernández, J.M. Electrochemical Advanced Oxidation Discoloration and Removal of Three Brown Diazo Dyes Used in the Tannery Industry. J. Electroanal. Chem. 2020, 873, 114360. [CrossRef]

110. Moradi, M.; Moussavi, G. Enhanced Treatment of Tannery Wastewater Using the Electrocoagulation Process Combined with UVC/VUV Photoreactor: Parametric and Mechanistic Evaluation. Chem. Eng. J. 2019, 358, 1038-1046. [CrossRef]

111. Vaiano, V.; Iervolino, G. Facile Method to Immobilize ZnO Particles on Glass Spheres for the Photocatalytic Treatment of Tannery Wastewater. J. Colloid Interface Sci. 2018, 518, 192-199. [CrossRef] [PubMed]

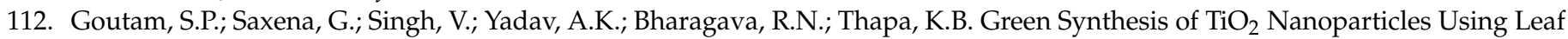
Extract of Jatropha curcas L. for Photocatalytic Degradation of Tannery Wastewater. Chem. Eng. J. 2018, 336, 386-396. [CrossRef]

113. Tien, T.T.; Luu, T.L. Electrooxidation of Tannery Wastewater with Continuous Flow System: Role of Electrode Materials. Environ. Eng. Res. 2020, 25, 324-334. [CrossRef]

114. Korpe, S.; Rao, P.V. Application of advanced oxidation processes and cavitation techniques for treatment of tannery wastewaterA review. J. Environ. Chem. Eng. 2021, 9, 105234. [CrossRef]

115. Rahim Pouran, S.; Abdul Aziz, A.R.; Wan Daud, W.M.A. Review on the main advances in photo-Fenton oxidation system for recalcitrant wastewaters. J. Ind. Eng. Chem. 2015, 21, 53-69. [CrossRef]

116. Arslan-Alaton, I.; Gurses, F. Photo-Fenton-like and photo-fenton-like oxidation of Procaine Penicillin G formulation effluent. J. Photochem. Photobiol. A Chem. 2004, 3, 165-175. [CrossRef]

117. Sivakumar, V.; Anna, J.L.; Vijayeeswarri, J.; Swaminathan, G. Ultrasound assisted enhancement in natural dye extraction from beetroot for industrial applications and natural dyeing of leather. Ultrason. Sonochem. 2009, 16, 782-789. [CrossRef]

118. Schrank, S.G.; José, H.J.; Moreira, R.F.P.M.; Schröder, H.F. Applicability of fenton and $\mathrm{H}_{2} \mathrm{O}_{2} / \mathrm{UV}$ reactions in the treatment of tannery wastewaters. Chemosphere 2005, 60, 644-655. [CrossRef]

119. Jiménez, E.; Gilles, M.K.; Ravishankara, A.R. Kinetics of the reactions of the hydroxyl radical with $\mathrm{CH}_{3} \mathrm{OH}$ and $\mathrm{C}_{2} \mathrm{H}_{5} \mathrm{OH}$ between 235 and 360 K. J. Photochem. Photobiol. A Chem. 2003, 157, 237-245. [CrossRef]

120. Sun, X.; Liu, J.; Ji, L.; Wang, G.; Zhao, S.; Yoon, J.Y.; Chen, S. A review on hydrodynamic cavitation disinfection: The current state of knowledge. Sci. Total Environ. 2020, 737. [CrossRef] [PubMed]

121. Gogate, P.R.; Patil, P.N. Combined treatment technology based on synergism between hydrodynamic cavitation and advanced oxidation processes. Ultrason. Sonochem. 2015, 25, 60-69. [CrossRef] [PubMed]

122. Ambrogi, E.; Asenath-Smith, E.; Ballard, W.; Moores, L.; Brame, J. Cross-Comparison of Advanced Oxidation Processes for Remediation of Organic Pollutants in Water Treatment Systems. In ERDC Program Element 622720048, "Industrial Operations Pollution Control Guidance"; U.S. Army Corps of Engineers: Washington, DC, USA, 2019.

123. Report, I.T.; Bolton, J.R.; Bircher, K.G.; Tumas, W.; Tolman, C.A. Figures-of-merit for the technical development and application of advanced electric- and solar-driven systems (IUPAC Technical Report). Pure Appl. Chem. 2001, 73, 627-637.

124. Capodaglio, A.G. Contaminants of emerging concern removal by high-energy oxidation-reduction processes: State of the art. Appl. Sci. 2019, 9, 4562. [CrossRef]

125. Wardenier, N.; Liu, Z.; Nikiforov, A.; Van Hulle, S.W.H.; Leys, C. Micropollutant elimination by $\mathrm{O}_{3}$, UV and plasma-based AOPs: An evaluation of treatment and energy costs. Chemosphere 2019, 234, 715-724. [CrossRef]

126. Soares, P.A.; Silva, T.F.C.V.; Ramos Arcy, A.; Souza, S.M.A.G.U.; Boaventura, R.A.R.; Vilar, V.J.P. Assessment of AOPs as a polishing step in the decolourisation of bio-treated textile wastewater: Technical and economic considerations. J. Photochem. Photobiol. A Chem. 2016, 317, 26-38. [CrossRef]

127. Mahamuni, N.N.; Adewuyi, Y.G. Advanced oxidation processes (AOPs) involving ultrasound for waste water treatment: A review with emphasis on cost estimation. Ultrason. Sonochem. 2010, 17, 990-1003. [CrossRef]

128. Gomes, A.I.; Soares, T.F.; Silva, T.F.C.V.; Boaventura, R.A.R.; Vilar, V.J.P. Ozone-driven processes for mature urban landfill leachate treatment: Organic matter degradation, biodegradability enhancement and treatment costs for different reactors configuration. Sci. Total Environ. 2020, 724. [CrossRef] 
129. Isarain-chávez, E.; De, C.; Godínez, L.A.; Brillas, E.; Peralta-hernández, J.M. Comparative study of electrochemical water treatment processes for a tannery wastewater effluent. J. Electroanal. Chem. 2014, 713, 62-69. [CrossRef]

130. Vijayalakshmi, P.; Raju, G.B.; Gnanamani, A. Advanced oxidation and electrooxidation as tertiary treatment techniques to improve the purity of tannery wastewater. Ind. Eng. Chem. Res. 2011, 50, 10194-10200. [CrossRef]

131. Lofrano, G.; Meriç, S.; Zengin, G.E.; Orhon, D. Chemical and Biological Treatment Technologies for Leather Tannery Chemicals and Wastewaters: A Review. Sci. Total Environ. 2013, 461, 265-281. [CrossRef]

132. Mpofu, A.B.; Oyekola, O.O.; Welz, P.J. Anaerobic treatment of tannery wastewater in the context of a circular bioeconomy for developing countries. J. Clean. Prod. 2021, 296, 126490. [CrossRef]

133. GracePavithra, K.; Jaikumar, V.; Kumar, P.S.; SundarRajan, P.S. A review on cleaner strategies for chromium industrial wastewater: Present research and future perspective. J. Clean. Prod. 2019, 228, 580-593. [CrossRef]

134. Lei, C.; Lin, Y.; Zeng, Y.; Wang, Y.; Yuan, Y.; Shi, B. A Cleaner Deliming Technology with Glycine for Ammonia-Nitrogen Reduction in Leather Manufacture. J. Clean. Prod. 2020, 245, 118900. [CrossRef]

135. Haydar, S.; Aziz, J.A.; Ahmad, M.S. Biological Treatment of Tannery Wastewater Using Activated Sludge Process. Pak. J. Eng. Appl. Sci. 2007, 1, 61-66.

136. Fathima, A.; Rao, J.R.; Unni Nair, B. Trivalent Chromium Removal from Tannery Effluent Using Kaolin-Supported Bacterial Biofilm of Bacillus Sp Isolated from Chromium Polluted Soil. J. Chem. Technol. Biotechnol. 2012, 87, 271-279. [CrossRef]

137. Shanmugam, B.K.; Easwaran, S.N.; Mohanakrishnan, A.S.; Kalyanaraman, C.; Mahadevan, S. Biodegradation of Tannery Dye Effluent Using Fenton's Reagent and Bacterial Consortium: A Biocalorimetric Investigation. J. Environ. Manag. 2019, 242, 106-113. [CrossRef]

138. Kanagaraj, J.; Senthil Velan, T.; Mandal, A.B. Biological Method for Decolourisation of an Azo Dye: Clean Technology to Reduce Pollution Load in Dye Waste Water. Clean Technol. Environ. Policy 2012, 14, 565-572. [CrossRef]

139. Sundar, K.; Sadiq, I.M.; Mukherjee, A.; Chandrasekaran, N. Bioremoval of Trivalent Chromium Using Bacillus Biofilms through Continuous Flow Reactor. J. Hazard. Mater. 2011, 196, 44-51. [CrossRef] [PubMed]

140. Mahmood, S.; Khalid, A.; Mahmood, T.; Arshad, M.; Ahmad, R. Potential of Newly Isolated Bacterial Strains for Simultaneous Removal of Hexavalent Chromium and Reactive Black-5 Azo Dye from Tannery Effluent. J. Chem. Technol. Biotechnol. 2013, 88, 1506-1513. [CrossRef]

141. Chandrasekaran, K.; Selvaraj, H.; George, H.S.; Sundaram, M.; Khaleel, T.M. A Hybrid Treatment Process for Product Recycling from Tannery Process Effluent and Soak Liquor. J. Environ. Chem. Eng. 2020, 8, 103516. [CrossRef]

142. Sathishkumar, K.; Narenkumar, J.; Selvi, A.; Murugan, K.; Babujanarthanam, R.; Rajasekar, A. Treatment of Soak Liquor and Bioelectricity Generation in Dual Chamber Microbial Fuel Cell. Environ. Sci. Pollut. Res. 2018, 25, 11424-11430. [CrossRef]

143. Muneeb, M.; Rashid, M.; Javid, A.; Bukhari, S.M.; Ali, W.; Hasan, A.; Akmal, M.; Hussain, A. Concomitant Treatment of Tannery and Paper Mill Effluents Using Extremely Metal-Tolerant Sulphate-Reducing Bacteria. Environ. Process. 2020, 7, 243-253. [CrossRef]

144. Chandrasekaran, K.; Selvaraj, H.; Sundaram, M. Electrochemical Oxidation with the Aerobic Pretreatment Process for Sulfate-Rich Tannery Effluent. Environ. Sci. Pollut. Res. 2019, 26, 12194-12204. [CrossRef] [PubMed]

145. Elahi, A.; Ajaz, M.; Rehman, A.; Vuilleumier, S.; Khan, Z.; Hussain, S.Z. Isolation, Characterization, and Multiple Heavy MetalResistant and Hexavalent Chromium-Reducing Microbacterium testaceum B-HS2 from Tannery Effluent. J. King Saud Univ. Sci. 2019, 31, 1437-1444. [CrossRef]

146. Huang, G.; Ou, L.; Pan, F.; Wang, Y.; Fan, G.; Liu, G.; Wang, W. Isolation of a Novel Heterotrophic Nitrification-Aerobic Denitrification Bacterium Serratia Marcescens CL1502 from Deep-Sea Sediment. Environ. Eng. Sci. 2017, 34, 453-459. [CrossRef]

147. Chaudhuri, G.; Dey, P.; Dalal, D.; Venu-Babu, P.; Thilagaraj, W.R. A Novel Approach to Precipitation of Heavy Metals from Industrial Effluents and Single-Ion Solutions Using Bacterial Alkaline Phosphatase. Water Air Soil Pollut. 2013, 224, 1625. [CrossRef]

148. Pire-Sierra, M.C.; Cegarra-Badell, D.D.; Carrasquero-Ferrer, S.J.; Angulo-Cubillan, N.E.; Díaz-Montiel, A.R. Nitrogen and COD removal from tannery wastewater using biological and physicochemical treatments. Rev. Fac. Ing. Univ. Antioq. 2016, 80, 63-73. [CrossRef]

149. Kim, I.-S.; Ekpeghere, K.I.; Ha, S.-Y.; Kim, B.-S.; Song, B.; Kim, J.-T.; Kim, H.-G.; Koh, S.-C. Full-Scale Biological Treatment of Tannery Wastewater Using the Novel Microbial Consortium BM-S-1. J. Environ. Sci. Health Part A 2014, 49, 355-364. [CrossRef]

150. Vijayaraj, A.S.; Mohandass, C.; Joshi, D.; Rajput, N. Effective Bioremediation and Toxicity Assessment of Tannery Wastewaters Treated with Indigenous Bacteria. 3 Biotech 2018, 8, 428. [CrossRef]

151. Garg, S.K.; Garg, S.; Tripathi, M.; Singh, K. Microbial Treatment of Tannery Effluent by Augmenting Psychrotrophic Pseudomonas putida Isolate. Environ. Pollut. Prot. 2018, 3, 23-39. [CrossRef]

152. Uddin, M.J.; Jeong, Y.-K.; Lee, W. Microbial Fuel Cells for Bioelectricity Generation through Reduction of Hexavalent Chromium in Wastewater: A Review. Int. J. Hydrogen Energy 2021, 46, 11458-11481. [CrossRef]

153. Munoz-Cupa, C.; Hu, Y.; Xu, C.; Bassi, A. An Overview of Microbial Fuel Cell Usage in Wastewater Treatment, Resource Recovery and Energy Production. Sci. Total Environ. 2021, 754, 142429. [CrossRef] [PubMed]

154. Sawasdee, V.; Pisutpaisal, N. Simultaneous Pollution Treatment and Electricity Generation of Tannery Wastewater in Air-Cathode Single Chamber MFC. Int. J. Hydrogen Energy 2016, 41, 15632-15637. [CrossRef]

155. Chen, F.; Zeng, S.; Luo, Z.; Ma, J.; Zhu, Q.; Zhang, S. A Novel MBBR-MFC Integrated System for High-Strength Pulp/Paper Wastewater Treatment and Bioelectricity Generation. Sep. Sci. Technol. 2020, 55, 2490-2499. [CrossRef] 
156. Naina Mohamed, S.; Ajit Hiraman, P.; Muthukumar, K.; Jayabalan, T. Bioelectricity Production from Kitchen Wastewater Using Microbial Fuel Cell with Photosynthetic Algal Cathode. Bioresour. Technol. 2020, 295, 122226. [CrossRef]

157. Amutha, R.; Josiah, J.J.M.; Adriel Jebin, J.; Jagannathan, P.; Berchmans, S. Chromium Hexacyanoferrate as a Cathode Material in Microbial Fuel Cells. J. Appl. Electrochem. 2010, 40, 1985-1990. [CrossRef]

158. Włodarczyk, P.P.; Włodarczyk, B. Wastewater Treatment and Electricity Production in a Microbial Fuel Cell with Cu-B Alloy as the Cathode Catalyst. Catalysts 2019, 9, 572. [CrossRef]

159. Tanikkul, P.; Pisutpaisal, N. Membrane-Less MFC Based Biosensor for Monitoring Wastewater Quality. Int. J. Hydrogen Energy 2018, 43, 483-489. [CrossRef]

160. Liu, L.; Yuan, Y.; Li, F.; Feng, C. In-Situ Cr(VI) Reduction with Electrogenerated Hydrogen Peroxide Driven by Iron-Reducing Bacteria. Bioresour. Technol. 2011, 102, 2468-2473. [CrossRef] [PubMed]

161. Singhvi, P.; Chhabra, M. Simultaneous Chromium Removal and Power Generation Using Algal Biomass in a Dual Chambered Salt Bridge Microbial Fuel Cell. J. Bioremediat. Biodegrad. 2013, 4, 190. [CrossRef]

162. Sophia, A.C.; Saikant, S. Reduction of Chromium(VI) with Energy Recovery Using Microbial Fuel Cell Technology. J. Water Process Eng. 2016, 11, 39-45. [CrossRef]

163. Watanabe, K. Recent Developments in Microbial Fuel Cell Technologies for Sustainable Bioenergy. J. Biosci. Bioeng. 2008, 106, 528-536. [CrossRef]

164. Sonawane, J.M.; Adeloju, S.B.; Ghosh, P.C. Landfill Leachate: A Promising Substrate for Microbial Fuel Cells. Int. J. Hydrogen Energy 2017, 42, 23794-23798. [CrossRef]

165. Rittmann, B.E. Opportunities for Renewable Bioenergy Using Microorganisms. Biotechnol. Bioeng. 2008, 100, $203-212$. [CrossRef] [PubMed]

166. Zhang, B.; Feng, C.; Ni, J.; Zhang, J.; Huang, W. Simultaneous Reduction of Vanadium (V) and Chromium (VI) with Enhanced Energy Recovery Based on Microbial Fuel Cell Technology. J. Power Sources 2012, 204, 34-39. [CrossRef]

167. Tandukar, M.; Huber, S.J.; Onodera, T.; Pavlostathis, S.G. Biological Chromium(VI) Reduction in the Cathode of a Microbial Fuel Cell. Environ. Sci. Technol. 2009, 43, 8159-8165. [CrossRef]

168. Tang, D.Y.Y.; Khoo, K.S.; Chew, K.W.; Tao, Y.; Ho, S.-H.; Show, P.L. Potential Utilization of Bioproducts from Microalgae for the Quality Enhancement of Natural Products. Bioresour. Technol. 2020, 304, 122997. [CrossRef]

169. Ballén-Segura, M.; Hernández Rodríguez, L.; Parra Ospina, D.; Vega Bolaños, A.; Pérez, K. Using Scenedesmus sp. for the Phycoremediation of Tannery Wastewater. Tecciencia 2016, 11, 69-75. [CrossRef]

170. Sydney, E.B.; Schafranski, K.; Barretti, B.R.V.; Sydney, A.C.N.; Zimmerman, J.F.D.; Cerri, M.L.; Mottin Demiate, I. Biomolecules from Extremophile Microalgae: From Genetics to Bioprocessing of a New Candidate for Large-Scale Production. Process Biochem. 2019, 87, 37-44. [CrossRef]

171. Sadvakasova, A.K.; Akmukhanova, N.R.; Bolatkhan, K.; Zayadan, B.K.; Usserbayeva, A.A.; Bauenova, M.O.; Akhmetkaliyeva, A.E.; Allakhverdiev, S.I. Search for New Strains of Microalgae-Producers of Lipids from Natural Sources for Biodiesel Production. Int. J. Hydrogen Energy 2019, 44, 5844-5853. [CrossRef]

172. Das, C.; Ramaiah, N.; Pereira, E.; Naseera, K. Efficient Bioremediation of Tannery Wastewater by Monostrains and Consortium of Marine Chlorella sp. and Phormidium sp. Int. J. Phytoremed. 2018, 20, 284-292. [CrossRef] [PubMed]

173. Delgadillo-Mirquez, L.; Lopes, F.; Taidi, B.; Pareau, D. Nitrogen and Phosphate Removal from Wastewater with a Mixed Microalgae and Bacteria Culture. Biotechnol. Rep. 2016, 11, 18-26. [CrossRef] [PubMed]

174. Chen, C.-Y.; Kuo, E.-W.; Nagarajan, D.; Ho, S.-H.; Dong, C.-D.; Lee, D.-J.; Chang, J.-S. Cultivating Chlorella sorokiniana AK1 with Swine Wastewater for Simultaneous Wastewater Treatment and Algal Biomass Production. Bioresour. Technol. 2020, 302, 122814. [CrossRef]

175. Msanne, J.; Polle, J.; Starkenburg, S. An Assessment of Heterotrophy and Mixotrophy in Scenedesmus and Its Utilization in Wastewater Treatment. Algal Res. 2020, 48, 101911. [CrossRef]

176. Vidyalaxmi; Kaushik, G.; Raza, K. Potential of Novel Dunaliella salina from Sambhar Salt Lake, India, for Bioremediation of Hexavalent Chromium from Aqueous Effluents: An Optimized Green Approach. Ecotoxicol. Environ. Saf. 2019, 180, 430-438. [CrossRef]

177. Srinivasan, S.V.; Rema, T.; Chitra, K.; Sri Balakameswari, K.; Suthanthararajan, R.; Uma Maheswari, B.; Ravindranath, E.; Rajamani, S. Decolourisation of Leather Dye by Ozonation. Desalination 2009, 235, 88-92. [CrossRef]

178. Ansari, F.A.; Gupta, S.K.; Nasr, M.; Rawat, I.; Bux, F. Evaluation of Various Cell Drying and Disruption Techniques for Sustainable Metabolite Extractions from Microalgae Grown in Wastewater: A Multivariate Approach. J. Clean. Prod. 2018, 182, 634-643. [CrossRef]

179. Behera, M.; Dhali, D.; Chityala, S.; Mandal, T.; Bhattacharya, P.; Mandal, D.D. Evaluation of Performance of Planococcus sp. TRC1 an Indigenous Bacterial Isolate Monoculture as Bioremediator for Tannery Effluent. Desalin. Water Treat. 2016, 57, 13213-13224. [CrossRef]

180. Ajayan, K.V.; Selvaraju, M. Heavy Metal Induced Antioxidant Defense System of Green Microalgae and Its Effective Role in Phycoremediation of Tannery Effluent. Pak. J. Biol. Sci. 2012, 15, 1056-1062. [CrossRef]

181. Rose, P.; Dunn, K. A High Rate Ponding Unit Operation Linking Treatment of Tannery Effluent and Arthrospira (Spirulina) Biomass Production. 1: Process Development. Biomass Bioenergy 2013, 51, 183-188. [CrossRef] 
182. Ardila, L.; Godoy, R.; Montenegro, L. Sorption Capacity Measurement of Chlorella vulgaris and Scenedesmus acutus to Remove Chromium from Tannery Waste Water. Proc. IOP Conf. Ser. Earth Environ. Sci. 2017, 83, 12031. [CrossRef]

183. Nagabalaji, V.; Sivasankari, G.; Srinivasan, S.V.; Suthanthararajan, R.; Ravindranath, E. Nutrient removal from synthetic and secondary treated sewage and tannery wastewater through phycoremediation. Environ. Technol. 2019, 40, 784-792. [CrossRef]

184. Ajayan, K.V.; Harilal, C.C.; Selvaraju, M. Phycoremediation Resultant Lipid Production and Antioxidant Changes in Green Microalgae Chlorella sp. Int. J. Phytoremed. 2018, 20, 1144-1151. [CrossRef]

185. Saranya, D.; Shanthakumar, S. Effect of culture conditions on biomass yield of acclimatized microalgae in ozone pre-treated tannery effluent: A simultaneous exploration of bioremediation and lipid accumulation potential. J. Environ. Manag. 2020, 273, 111129. [CrossRef] [PubMed]

186. da Fontoura, J.T.; Rolim, G.S.; Mella, B.; Farenzena, M.; Gutterres, M. Defatted Microalgal Biomass as Biosorbent for the Removal of Acid Blue 161 Dye from Tannery Effluent. J. Environ. Chem. Eng. 2017, 5, 5076-5084. [CrossRef]

187. Sforza, E.; Kumkum, P.; Barbera, E.; Kumar, S. Bioremediation of industrial effluents: How a biochar pretreatment may increase the microalgal growth in tannery wastewater. J. Water Process Eng. 2020, 37, 101431. [CrossRef]

188. Salama, E.S.; Kurade, M.B.; Abou-Shanab, R.A.I.; El-Dalatony, M.M.; Yang, I.S.; Min, B.; Jeon, B.H. Recent progress in microalgal biomass production coupled with wastewater treatment for biofuel generation. Renew. Sustain. Energy Rev. 2017, 79, 1189-1211. [CrossRef]

189. Gendy, T.S.; El-Temtamy, S.A. Commercialization potential aspects of microalgae for biofuel production: An overview. Egypt. J. Pet. 2013, 22, 43-51. [CrossRef] 